\title{
Chicxulub impact spherules in the North Atlantic and Caribbean: age constraints and Cretaceous-Tertiary boundary hiatus
}

\author{
GERTA KELLER* ${ }^{*}$, HASSAN KHOZYEM $\ddagger$, THIERRY ADATTE $\ddagger$, NALLAMUTHU \\ MALARKODI , JORGE E. SPANGENBERG \& \& WOLFGANG STINNESBECK\| \\ *Department of Geosciences, Princeton University, Princeton NJ 08544, USA \\ $\ddagger$ Institut de Science de la Terre et de l'Environment (ISTE), Université de Lausanne, Lausanne, CH-1015 Switzerland \\ $\S$ Department of Geology, Bangalore University, Bangalore 560 056, India \\ \Mineralogy and Geochemistry Institute, University of Lausanne, Anthropole, Lausanne, CH-1015 Switzerland \\ ||Institute für Geowissenschaften der Universität Heidelberg, 69120 Heidelberg, Germany
}

(Received 1 July 2012; accepted 11 December 2012; first published online 21 March 2013)

\begin{abstract}
The Chicxulub impact is commonly believed to have caused the Cretaceous-Tertiary boundary mass extinction and a thin impact spherule layer in the North Atlantic and Caribbean is frequently cited as proof. We evaluated this claim in the seven best North Atlantic and Caribbean Cretaceous-Tertiary boundary sequences based on high-resolution biostratigraphy, quantitative faunal analyses and stable isotopes. Results reveal a major Cretaceous-Tertiary boundary unconformity spanning most of Danian subzone P1a(1) and Maastrichtian zones CF1-CF2 ( 400 ka) in the NW Atlantic Bass River core, ODP Sites 1049A, 1049C and 1050C. In the Caribbean ODP Sites 999B and 1001B the unconformity spans from the early Danian zone P1a(1) through to zones CF1-CF4 ( $23 \mathrm{Ma}$ ). Only in the Demerara Rise ODP Site 1259B is erosion relatively minor and restricted to the earliest Danian zone P0 and most of subzone P1a(1) ( 150 ka). In all sites examined, Chicxulub impact spherules are reworked into the early Danian subzone P1a(1) about 150-200 ka after the mass extinction. A similar pattern of erosion and redeposition of impact spherules in Danian sediments has previously been documented from Cuba, Haiti, Belize, Guatemala, south and central Mexico. This pattern can be explained by intensified Gulf stream circulation at times of climate cooling and sea level changes. The age of the Chicxulub impact cannot be determined from these reworked impact spherule layers, but can be evaluated based on the stratigraphically oldest spherule layer in NE Mexico and Texas, which indicates that this impact predates the Cretaceous-Tertiary boundary by about 130-150 ka.
\end{abstract}

Keywords: Chicxulub, impact spherules, Cretaceous-Tertiary boundary unconformity, North Atlantic.

\section{Introduction}

The age of the Chicxulub impact has been a contentious issue ever since the discovery of the impact structure on the Yucatan peninsula and its initial tentative link to the Cretaceous-Tertiary boundary (KTB; also called $\mathrm{K}-\mathrm{P}$ or $\mathrm{K}-\mathrm{Pg}$ ) mass extinction, based mainly on the stratigraphic position of impact spherules relative to the KTB in Haiti and NE Mexico (e.g. Maurrasse \& Sen, 1991; Smit et al. 1992; Stinnesbeck et al. 1993; Smit, 1999). Over the past 20 years, data from over 80 localities throughout the Caribbean, Central and North America (Fig. 1) have provided variable results with impact spherule layers in latest Maastrichtian and early Danian sediments (Keller et al. 2003a, b, 2007, $2009,2011)$. To understand the age and nature of spherule deposition we must comprehend this regional stratigraphic variation and consider all evidence to determine what really happened over $65 \mathrm{Ma}$ ago.

The strongest age claims for a KTB age for the Chicxulub impact are based on a select few deepsea localities where a single thin impact spherule layer is reported directly between the Cretaceous and Paleocene. These localities include the Bass River Core of New Jersey, NW Atlantic Site 1049, Caribbean Site

$\dagger$ †uthor for correspondence: gkeller@princeton.edu
1001 and SW Atlantic Site 1259 (Olsson et al. 1997; Sigurdsson et al. 1997; Norris, Huber \& Self-Trail 1999; Norris et al. 2000; Klaus et al. 2000; MartinezRuiz et al. 2001; Huber, MacLeod \& Norris, 2002; MacLeod et al. 2007). This single spherule layer is commonly cited as proof that the Chicxulub impact caused the KTB mass extinction. In this scenario, the presence of multiple spherule layers in most other localities is attributed to an impact generated tsunami that caused gravity flows, slumps or liquefaction sucking spherules from the KTB into Maastrichtian sediments (Schulte et al. 2010).

The simplicity of a thin spherule layer separating Maastrichtian and Danian sediments is appealing as an age indicator but difficult to reconcile with regional data. Are these sections complete across the KTB as claimed? If not, is there a pattern of spherule erosion and redeposition? To answer these questions a high-resolution quantitative planktic foraminiferal biostratigraphy is required, which does not exist for these localities. This type of data can determine not only the presence or absence of biozones, but also whether sedimentation is complete in each biozone based on the abrupt onset or termination of species populations (e.g. the sudden appearance or disappearance of species that dominate the assemblage). For these reasons 


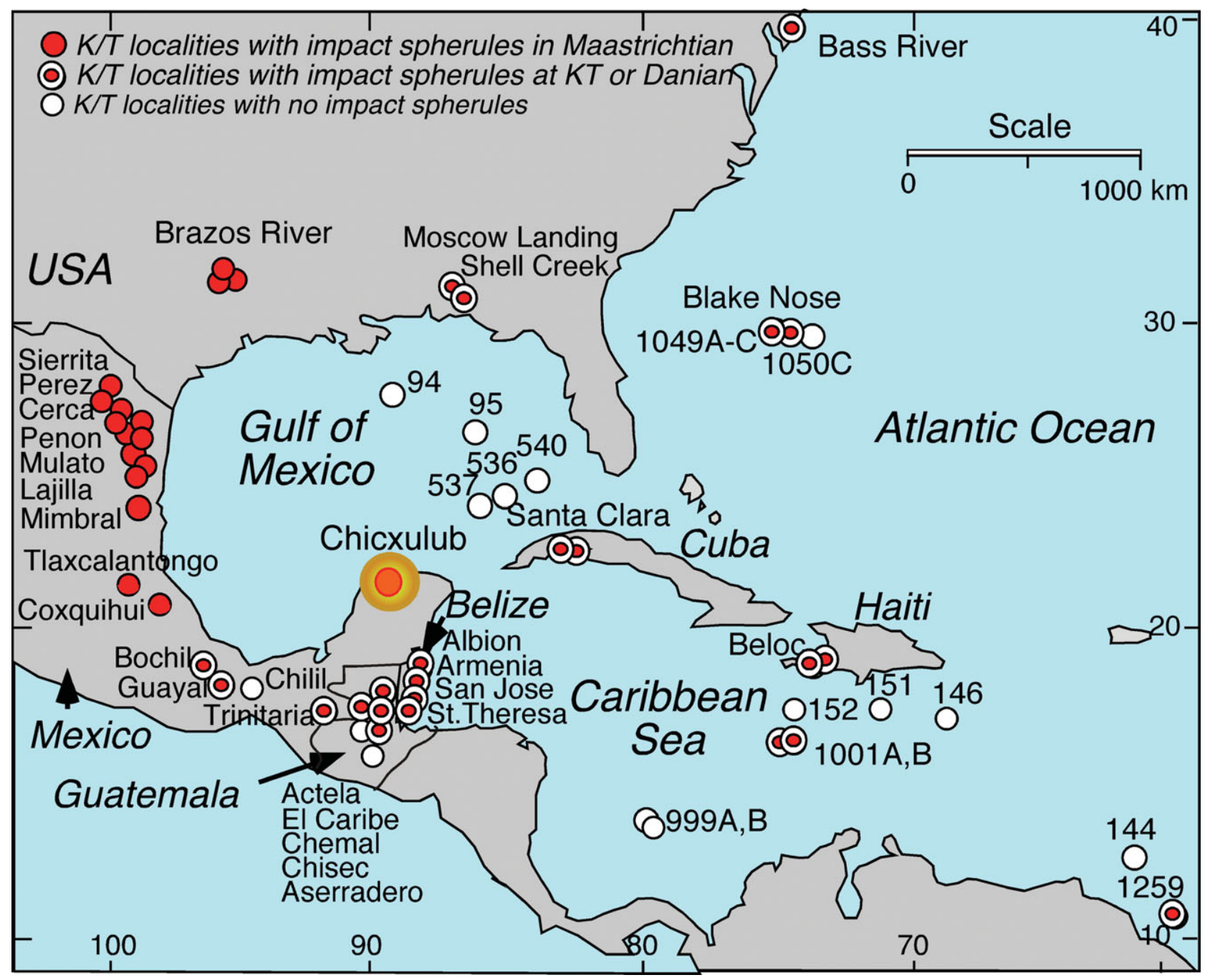

Figure 1. (Colour online) Cretaceous-Tertiary boundary localities studied for this paper in the NW Atlantic ODP Sites 999B, 1001B, 1049A, 1049C, 1050C, 1259B and Bass River, and other localities with impact spherules surrounding the Chicxulub impact crater on the Yucatan Peninsula with stratigraphical positions of impact spherules.

we examined the KTB sequences at Bass River, New Jersey, and ODP Sites 1049A, 1049C, 1050C, 999B, 1001B and 1259B (Fig. 1) based on: (1) highresolution planktic foraminiferal biostratigraphy; (2) quantitative species abundance data as indicators of biozone truncation and hiatuses; (3) completeness of the KT boundary transition; (4) stable isotopes; and (5) stratigraphic position of the spherule layer relative to the KTB. The KTB was identified based on the five criteria of the El Kef stratotype: KTB characteristic clay layer, $\delta^{13} \mathrm{C}$ shift, iridium anomaly, mass extinction and evolution of Danian species (Cowie, Ziegler \& Remane, 1989; Keller, Li \& MacLeod, 1995; Remane et al. 1999).

\section{Chicxulub impact controversy - background}

The ongoing KT impact controversy is now over three decades old and was recently summarized from very different viewpoints in Schulte et al. (2010) and Keller (2011a). At the core of this controversy is the age of the Chicxulub impact and the cause of the KTB mass extinction. The most critical evidence comes from NE Mexico, Texas and the Chicxulub impact crater core Yaxcopoil-1. In NE Mexico and Texas impact spherule layers are at the base of a sandstone complex that infills submarine channels along the slope of the Gulf of Mexico (Sohl et al. 1991) and at the margin of the Western Interior Seaway (Keller \& Adatte, 2011), respectively. The controversy revolves over the origin of this sandstone complex. Was it deposited as the result of an impact-generated tsunami at the KTB (Smit et al. 1996; Schulte et al. 2010), or was deposition long term and associated with erosion, transport and redeposition during the sea-level fall near the end of the Maastrichtian (Keller et al. 1997, 2009; Adatte, Stinnesbeck \& Keller, 1996; Adatte, Keller \& Stinnesbeck, 2002).

The sandstone complex is deposited in submarine channels at depths of 500-1000 m in NE Mexico and in shallow inner neritic environments $(<50 \mathrm{~m}$ depth) in Texas. Three units are generally present: Unit 1 at the base consists of one to three layers of spherule-rich, sandy and glauconitic sediments enriched in reworked 
shallow water debris (e.g. plant remains, shallow water foraminifera; Keller et al. 1997; Alegret, Molina \& Thomas, 2001; Alegret et al. 2002). Thin sandstone or limestone layers separate the spherule layers (Keller et al. 2007, 2009; Adatte, Keller \& Baum, 2011). Unit 2 in NE Mexico consists of a thick sandstone with two to three thin volcanic-rich (zeolite) layers (Adatte, Stinnesbeck \& Keller, 1996). Unit 3 at the top consists of alternating sandy shale and marl layers with abundant burrows (Ekdale \& Stinnesbeck, 1998). The KTB is above this unit.

The number of spherule layers in the sandstone complex, or in the Danian above and Maastrichtian below, their mineralogical and fossil contents and nature of deposition are variable. For example, at El Penon and El Mimbral in NE Mexico two spherule layers at the base of the sandstone complex are separated by a $15-20 \mathrm{~cm}$ thick limestone bed with occasional large burrows infilled with spherules, in other localities this limestone bed is truncated by erosion (e.g. La Lajilla, Fig. 1; Lopez-Oliva \& Keller, 1996; Adatte, Stinnesbeck \& Keller, 1996; Keller et al. 2003b; Stueben et al. 2005). At El Penon an additional spherule layer is interbedded in upper Maastrichtian marls up to 4-5 $\mathrm{m}$ below the sandstone complex (Keller et al. 2009), as also observed at Loma Cerca (Schulte et al. 2003). In the Brazos sections of Texas two to three spherule layers are separated by thin sandstones at the base of the sandstone complex and up to $1 \mathrm{~m}$ of latest Maastrichtian sediments are between the KTB and the top of the sandstone complex (Gale, 2006; Schulte et al. 2006; Prauss, 2009; Keller et al. 2007, 2011; Adatte, Keller \& Baum, 2011). In the Chicxulub impact crater core Yaxcopoil-1 a $50 \mathrm{~cm}$ thick limestone separates the impact breccia from the KTB (Arz, Alegret \& Arenillas, 2004; Keller, Adatte \& Stinnesbeck, 2004a; Keller et al. 2004b; Smit, van der Gaast \& Lustenhouwer, 2004).

In central and southern Mexico (e.g. Tlaxcalantongo/La Ceiba, Coxquihui, Bochil, Guayal) impact spherules are found at or just below the KTB (Arz et al. 2001; Arenillas et al. 2006) as well as in the early Danian zone P1a (Stinnesbeck et al. 2002; Keller et al. 2003b; Keller, 2008; Fig. 1). In Guatemala and Belize, all impact spherules are in early Danian zone P1a sediments (Keller et al. 2003a). In Cuba impact spherules are reported at the top of a conglomerate (Alegret et al. 2005), as well as a $2 \mathrm{~cm}$ thick layer in the overlying early Danian zone P1a (Keller, 2008). Four sections analyzed in Haiti also revealed impact spherules in early Danian zone P1a sediments (Keller et al. 2001, 2003b). From the North Atlantic (Bass River core, ODP Sites 1049, 1001B and 1259) a thin spherule layer is reported at the KTB (Olsson et al. 1997; Sigurdsson et al. 1997; Norris et al. 1998; Norris, Huber \& Self-Trail, 1999; MacLeod et al. 2007).

\section{2.a. Nature of impact spherule deposition}

The earliest and most commonly advocated scenario for the sandstone complex and impact spherules as impact generated tsunami deposits precisely at the KTB is based on its proximity to the KTB mass extinction and the KTB iridium anomaly, and the belief that no other major event occurred or could have caused the mass extinction (e.g. Bourgeois et al. 1988; Smit et al. 1992, 1996; Alegret et al. 2002, 2005; Arenillas et al. 2006; Schulte et al. 2003, 2006, 2010). In this scenario, the KTB clay and global iridium anomaly is attributed to the Chicxulub impact, whereas pyrite, glauconite, and sanidine spherules commonly present in the KTB clay are interpreted as altered Chicxulub impact spherules (Smit, 1999), although there is no evidence for these claims. Various sedimentological, mineralogical, stratigraphical and palaeontological data argue against this KTB impact-tsunami scenario. For example, in NE Mexico the multiple spherule layers separated by limestone, containing rare burrows infilled with spherules, could not have been deposited within hours to days (Keller et al. 1997, 2009). The shallow water debris and benthic foraminifera in the spherule layers of deep-water deposits (Alegret, Molina \& Thomas, 2001; Alegret et al. 2002; Alegret \& Thomas, 2004) require prior spherule deposition in shallow water followed by erosion and transport. The two to three correlative zeolite layers in the middle unit of the sandstone complex require depositional events separated by time (Adatte, Stinnesbeck \& Keller, 1996). The burrowed intervals in the alternating sandy shale and marl layers of the upper part of the sandstone complex indicate colonization of the seafloor during deposition (Ekdale \& Stinnesbeck, 1998). Similarly, the truncated burrows across the hummocky sandstones in the Brazos sections of Texas and in the overlying layers mark multiple recolonization of the seafloor (Gale, 2006; Adatte, Keller \& Baum, 2011). At the base of the Brazos sandstone complex the presence of lithified clasts with impact spherules, including some in desiccation cracks, marks a history of prior spherule deposition followed by lithification, emersion, erosion, transport and redeposition (Adatte, Keller \& Baum, 2011; Keller et al. 2007, 2011).

All these characteristics of the sandstone complex suggest long-term deposition interrupted by gravity flows and channelized downslope transport possibly related to climate and sea level changes. Schulte et al. (2010, p. 1215) deny the presence of most of these welldocumented features and maintain rapid deposition by tsunami and gravity flows. Incongruously they claim that 'the presence of shallow water foraminifera in the clastic unit contradicts a long-term depositional sequence; if in situ, their presence requires unrealistically rapid relative sea-level changes of $>500 \mathrm{~m}$.' However, there never was a claim of in situ deposition of shallow benthic foraminifera in bathyal deposits, but rather downslope transport (Alegret, Molina \& Thomas, 2001; Alegret et al. 2002; Keller et al. 2003b, 2007, 2008). In contrast, to NE Mexico and Texas, impact spherules are generally found in early Danian sediments (zone P1a) of central and southern Mexico, Guatemala, Belize, Haiti and Cuba. This can be easily 
explained by reworking and redeposition of spherule deposits by intensified Gulf Stream circulation and sea level changes (e.g. Keller et al. 1993, 2003a; Watkins \& Self-Trail, 2005; Keller, 2008). These regions are rarely mentioned in the Chicxulub controversy.

\section{2.b. Age of Chicxulub impact}

The most critical part of the Chicxulub controversy is the question of the age of this impact. Based on the original five KTB-identifying criteria (mass extinction, evolution of the first Danian species, KTB clay and red layer, iridium anomaly, and $\delta^{13} \mathrm{C}$ shift; Cowie, Ziegler \& Remane, 1989; Keller, Li \& MacLeod, 1995; Remane et al. 1999), no KTB age can be assigned to the Chicxulub impact. A strong belief that the Chicxulub impact is the cause for the KTB catastrophe led to the proposal to use the mass extinction and impact ejecta as the sole KTB markers (Molina et al. 2006). This re-definition was embraced by KTB impact proponents who then claimed that the sandstone complex in NE Mexico and Texas and the clastic complex of southern Mexico and Cuba are equivalent to the KTB red layer and iridium anomaly at the El Kef stratotype in Tunisia (e.g. Alegret et al. 2005; Arenillas et al. 2006; Schulte et al. 2006, 2008, 2010; see review in Keller, 2008, $2011 b$ ). Rather than solving the age problem, defining Chicxulub as KTB age has led to circular reasoning; one cannot evaluate the age of the Chicxulub impact by defining it.

A wealth of biostratigraphical data contradicts a KTB age for the Chicxulub impact. For example, in the Brazos sections the $0.30 \mathrm{~m}$ to $1.0 \mathrm{~m}$ burrowed claystone between the sandstone complex and the true KTB contains latest Maastrichtian palynomorphs and planktic foraminifera that indicate deposition prior to the KTB mass extinction (Prauss, 2009; Keller et al. $2007,2009,2011)$. Schulte et al. $(2006,2008)$ reported this interval $(1.6 \mathrm{~m})$ as barren and attributed it to the earliest Danian on the basis that the sandstone complex with impact spherules is by definition equivalent to the KTB at El Kef (see Keller, 2011b). In addition, the lithified clasts with impact spherules at the base of the sandstone complex reveal a history of prior deposition, lithification, erosion, transport and redeposition all prior to the KTB (Keller et al. 2007; Adatte et al. 2011).

A major problem for a Chicxulub KTB age is the up to $2 \mathrm{~m}$ thick spherule layer in undisturbed bedded marls of upper Maastrichtian zone CF1 about $4 \mathrm{~m}$ below the sandstone complex at El Penon, which can be traced over $90 \mathrm{~m}$ before the outcrop dips below the surface (Keller et al. 2009). Schulte et al. (2010, p. 1215 ) interpret this and other spherule layers below the sandstone complex as 'lenslike ejecta deposits in Mexico generated by impact-related liquefaction and slumping, consistent with the single very-high-energy Chucxulub impact.' They do not explain the process by which spherules could have been injected as a layer at the same stratigraphic interval over $90 \mathrm{~m}$ and $4 \mathrm{~m}$ below their presumed origin, or the mechanism of liquefaction that could suck spherules $4 \mathrm{~m}$ into the underlying sediments and spread them out over $90 \mathrm{~m}$, or why shallow water debris is absent and spherules are cemented by calcite or consist of welded melt rock glass, which is inconsistent with the debris-rich spherule layers at the base of the sandstone complex from which they are supposed to have derived. A more parsimonious explanation is primary deposition and pre-KTB age for the stratigraphically older layer, but erosion and downslope transport of the spherule layers in the sandstone complex at a much later time during the sea-level fall near the end of the Maastrichtian.

Similarly problematic for a Chicxulub KTB age interpretation is the $50 \mathrm{~cm}$ thick limestone between the impact breccia and the true KTB in the impact crater core Yaxcopoil-1. Keller et al. (2004a, b) demonstrated that this limestone is laminated, contains five glauconitic clay layers with burrows, three $1 \mathrm{~cm}$ layers of oblique bedding near the base (called cross bedding by Schulte et al. 2010), late Maastrichtian (zone CF1) planktic foraminifera (see also Arz, Alegret \& Arenillas, 2004), stable isotope signals, and palaeomagnetic C29R signals. All of these features indicate long-term deposition near the end of the Maastrichtian and well after the Chicxulub impact. Smit, van der Gaast \& Lustenhouwer, (2004) interpreted this limestone as backwash and crater infill. Schulte et al. (2010) described the limestone layer as dolomitic sandstone, in part cross-bedded and containing ejecta clasts indicative of erosion and reworking. They ignored the glauconite layers, burrowing, stable isotopes, the latest Maastrichtian index species of zone CF1 and C29R palaeomagnetic data.

\section{Methods}

Cores across the KTB interval at ODP Sites 999B, 1001B, 1049A, 1049C, 1050C and 1259B were sampled at $1 \mathrm{~cm}, 5 \mathrm{~cm}$ and $10 \mathrm{~cm}$ intervals. Samples of about $1 \mathrm{~cm}^{3}$ were taken from central portions of the cores to avoid down-core contamination. For palaeontological analyses, samples were processed and washed through $36 \mu \mathrm{m}$ and $63 \mu \mathrm{m}$ screens following the procedure described in Keller et al. (1995).

Quantitative palaeontological analysis was performed on aliquots of 300-400 specimens in the $>63 \mu \mathrm{m}$ size fraction. The $36-63 \mu \mathrm{m}$ size fraction was examined for small species and counts were done for intervals where Danian species are more abundant in this size fraction. All specimens were identified and mounted on microslides for a permanent record. Preservation of foraminifera at Blake Nose ODP Sites 1049-1050 is excellent, though some calcite overgrowth and dissolution effects are apparent in sugary textures in the spherule layer. At Bass River and Site 1259B moderate dissolution has resulted in holes in the chambers of some Danian species. Strong dissolution and poor preservation at Sites 999B and 1001B prevented quantitative analysis and the species 
census data was obtained from both washed residues and thin sections.

Stable isotope analysis of samples from ODP Sites 1049A, 1049C, 1050C and 1259B was performed on the bulk fine fraction $(<63 \mu \mathrm{m})$. The abundance of reworked Cretaceous species in the early Danian of Sites 1049A and 1049C necessitated analysis of the Danian planktic species Parvularugoglobigerina eugubina and Chiloguembelina morsei to obtain a reliable Danian record. Analyses were performed at the Institute of Mineralogy and Geochemistry, Lausanne University, using a Thermo Fisher Scientific (Bremen, Germany) GasBench II preparation device interfaced with a Thermo Fisher Scientific Delta Plus $\mathrm{XL}$ continuous flow isotope ratio mass spectrometer (IRMS) (Revesz, Landwehr \& Keybl, 2001). Stable carbon and oxygen isotope ratios are reported in the delta notation as the per mil (\%o) deviation relative to the Vienna Pee Dee belemnite standard (VPDB). Analytical uncertainty $(2 \sigma)$ monitored by replicate analyses of the international calcite standard NBS19 and the laboratory standards Carrara Marble and Binn Dolomite is no greater than $\pm 0.05 \%$ or for $\delta^{13} \mathrm{C}$ and $\pm 0.1 \%$ of $\delta^{18} \mathrm{O}$.

\section{KT boundary definition and placement}

The controversy over the age of the Chicxulub impact is in no small measure the result of redefining the KTB as the impact ejecta layer based on the assumption that this impact caused the end-Cretaceous mass extinction. Unfortunately, this has led to confusion and circular reasoning. For example, Gradstein, Ogg \& Smith, (2004) proposed to define the KTB based on just two criteria 'the Ir anomaly associated with a major mass extinction.' This has proved impractical because small ( $\sim 1 \mathrm{ppb})$ Iridium anomalies may be remobilized and concentrated at redox boundaries thus leading to erroneous KTB placement (e.g. Graup \& Spettel, 1989; Kramar et al. 2001; Colodner et al. 1992; Lee, Wasserburg \& Kyte, 2003; Miller et al. 2010; Gertsch et al. 2011). Partly as a solution, Molina et al. (2006) proposed that any impact ejecta define the KTB (e.g. spherules, breccia, iridium anomaly, shocked quartz, spinels etc.). However, defining any presumed impact related material as KTB age leads to circular reasoning and rules out evaluating the true age of the Chicxulub impact. This has led to placing the KTB based on the select occurrence of impact spherules at the base of clastic deposits, at the base of breccia deposits of dubious origin in the Maastrichtian, and at spherule layers reworked into Danian sediments (e.g. Smit, 1999; Norris, Huber \& Self-Trail, 1999; Arenillas et al. 2006; Schulte et al. 2006, 2010).

These pitfalls can be avoided by returning to the unique defining and supporting KTB criteria of the GSSP, which consistently provide the most reliable KTB identification globally (Keller, 2011b). The KTB is globally defined based on five criteria developed at the El Kef stratotype section and point (GSSP) and
Elles parastratotype section in Tunisia (Cowie, Zielgler \& Remane, 1989; Keller, Li \& MacLeod, 1995; Keller et al. 2002; Remane et al. 1999). Two of the five are unique defining criteria: the mass extinction of $66 \%$ of planktic foraminiferal taxa and a few centimetres above the extinction horizon the first appearance (FA) of five Danian species (Parvularugoglobigerina extensa, Woodringina hornerstownensis, W. claytonensis, Globoconusa daubjergensis, Eoglobigerina eobulloides). Three are supporting criteria, which are not unique in the geological record but characterize the KTB: the clay layer, iridium anomaly and negative shift in $\delta^{13} \mathrm{C}$ values. All five criteria have been tested and successfully applied to hundreds of KTB sequences worldwide and their presence is powerful confirmation of environmental changes across this boundary event. These KTB criteria are applied in this study. However, the iridium anomaly in all sections is small, located in early Danian sediments and apparently represents reworking and remobilization of iridium (Kramar et al. 2001; Gertsch et al. 2011).

\section{Lithology and biostratigraphy}

Age control is based on high-resolution quantitative planktic foraminiferal biostratigraphy, which provides the best age resolution for palaeomagnetic chron $\mathrm{C} 29 \mathrm{r}$ spanning the KTB (Fig. 2). C29r below the KTB corresponds to planktic foraminiferal zones $\mathrm{CF} 1$ and CF2. The calcareous nannofossil zone Micula prinsii spans from the top of CF3 to the KTB. Above the KTB, C29r corresponds to Danian zones P0, P1a with subzones $\mathrm{P} 1 \mathrm{a}(1)$ and $\mathrm{P} 1 \mathrm{a}(2)$, which is encompassed by the lower part of nannofossil zone CP1a (or NP1a). Previous studies of the sections analyzed in this report have used standard nannofossil and/or planktic foraminiferal biostratigraphy without quantitative data, which is not well suited for evaluating the completeness of the KTB transition.

\section{5.a. Bass River core, New Jersey}

At Bass River, New Jersey $\left(39^{\circ} 36^{\prime} 42^{\prime \prime} \mathrm{N}\right.$, $\left.74^{\circ} 26^{\prime} 12^{\prime \prime} \mathrm{W}\right)$ the KTB transition was recovered in a relatively shallow water environment (palaeodepth $\sim 100 \mathrm{~m}$; Miller et al. 1998). Sediments consist of calcareous glauconitic silty shale with bivalve shells that disconformably underlie a $6 \mathrm{~cm}$ thick glauconitic impact spherule layer with clasts (1-6 cm, Fig. 3). A $\mathrm{mm}$ thin red-brown limonite layer separates the spherule layer from the overlying $6 \mathrm{~cm}$ thick glauconitic silty-sandy shale, which is interrupted by an $8-10 \mathrm{~cm}$ thick dense layer of phosphate clasts and Steinkerns with an erosion surface at the base. About $10 \mathrm{~cm}$ above this layer is a $5 \mathrm{~cm}$ thick burrowed interval truncated by a $16 \mathrm{~cm}$ core gap. The glauconitic silty shale above the core gap contains occasional phosphate clasts.

Planktic foraminifera from the sediments below the $6 \mathrm{~cm}$ thick spherule layer are relatively well preserved, though small, thin walled and fragile. A typical low 


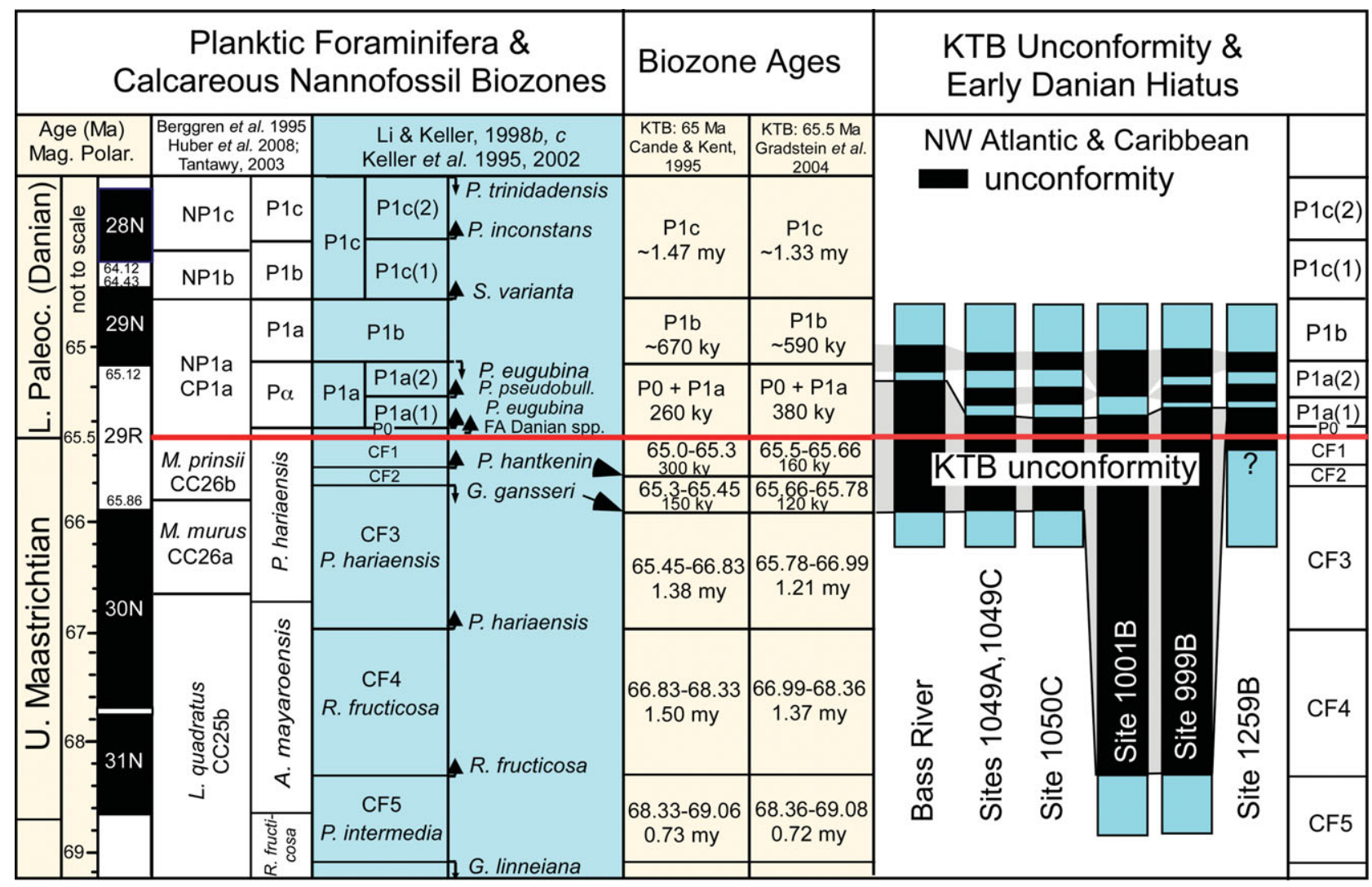

Figure 2. (Colour online) High-resolution planktic foraminiferal biostratigraphy in this study is based on Li \& Keller (1998b, $c$ ) for the Maastrichtian and Keller, Li \& MacLeod (1995) and Keller et al. (2002) for the early Danian. Biozone ages are calculated based on the time scales of Cande \& Kent (1995) and Gradstein, Ogg \& Smith (2004). The extent of the KTB unconformity in the NW Atlantic and Caribbean is based on this study.

diversity middle shelf planktic foraminiferal assemblage marks zone $\mathrm{CF} 3$ as indicated by the presence of Gansserina gansseri, the index species that marks the CF3-CF2 boundary (Fig. 3). This indicates erosion of the CF2-CF1 interval that spans the top $450 \mathrm{ka}$ of the Maastrichtian based on the time scale of Cande \& Kent (1995), or 280 ka based on Gradstein, Ogg \& Smith, (2004) (Fig. 2). Olsson et al. (1997) reported Micula prinsii in the $8 \mathrm{~cm}$ below the spherule layer, which is consistent with the overlap of this species in the upper part of zone CF3.

The spherule layer contains rare Cretaceous planktic foraminifera (e.g. Planoglobulina brazoensis, P. carseyae, Rugoglobigerina rugosa, $R$. macrocephala; Fig. 3). The $6 \mathrm{~cm}$ immediately above the spherule layer contains common small Cretaceous species (KT survivors or reworked) and a diverse (11 species) early Danian assemblage including Parvularugoglobigerina eugubina, Parasubbotina pseudobulloides and Subbotina triloculinoides, which is characteristic of subzone $\mathrm{P} 1 \mathrm{a}(2)$ (upper part of P1a zone). Thus the total interval missing at the KTB unconformity includes zones CF1, CF2, P0, P1a(1) and most of P1a(2), and spans about $620 \mathrm{ka}$; Fig. 2). Just $6 \mathrm{~cm}$ above the spherule layer this Danian P1a(2) assemblage and Cretaceous species terminate at the phosphate clast layer, which marks another hiatus between P1a(2) and P1b (Figs 2, 3). Above this hiatus the zone P1b assemblage is dominated by Chiloguembelina morsei, Praemurica taurica and Parasubbotina pseudobulloides.

\subsection{North Atlantic ODP Sites 1049A, 1049C and 1050C}

Ocean Drilling Program (ODP) Leg 171 drilled three holes at Site 1049 (A, B, C) on the eastern margin of Blake Nose $\left(30^{\circ} 08.5436^{\prime} \mathrm{N}, 76^{\circ} 06.7312^{\prime} \mathrm{W}\right)$ at a water depth of $2671 \mathrm{~m}$ (Norris et al. 1998; Norris, Huber \& Self-Trail, 1999). In each hole, located just $10 \mathrm{~m}$ apart from the next, the KTB transition was recovered along with a $10-15 \mathrm{~cm}$ thick impact spherule-rich layer. Site $1050 \mathrm{C}$ was drilled at a water depth of $2300 \mathrm{~m}, 330 \mathrm{~m}$ upslope from Site 1049 and at a distance of $10 \mathrm{~km}$ $\left(30^{\circ} 05.9953^{\prime} \mathrm{N}, 76^{\circ} 14.0997^{\prime} \mathrm{W}\right.$; Fig. 1). The KTB transition was also recovered but no impact spherules. We analyzed two holes at Site 1049 (A, C) and Site $1050 \mathrm{C}$ in order to insure replicable results and exclude artifacts of sampling or processing. All three sites analyzed show very similar lithologies, except for the absence of a spherule layer at Site 1050C (Fig. 4).

Upper Maastrichtian sediments at Sites 1049A and 1049C consist of disturbed, bioturbated, mottled light and darker grey nannofossil and foraminiferal ooze, which underlie the $10-15 \mathrm{~cm}$ thick spherule layer (Fig. 4). The spherule layer has a carbonate ooze matrix, irregular bedding, clasts of limestone, chalk and dolomite and is bounded by irregular surfaces. 


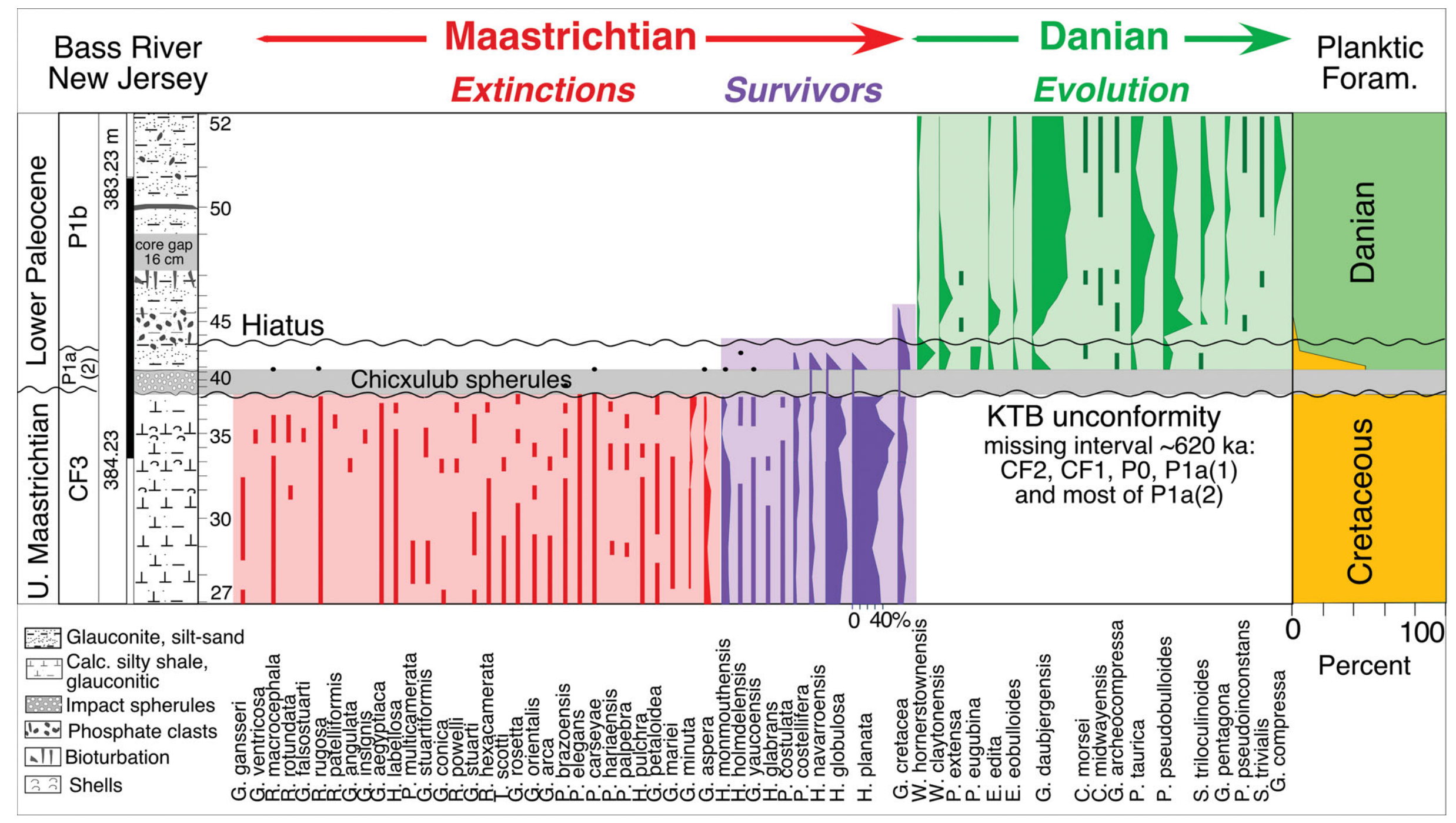

Figure 3. (Colour online) Biostratigraphy and relative species abundances of planktic foraminifera $(>63 \mu \mathrm{m})$ in the Bass River core of New Jersey. An unconformity at the base of the spherule layer spans from the early Danian subzone P1a(2) to P1a(1), P0 and late Maastrichtian zones CF1 and CF2 for a total of about 620 ka (time scale of Gradstein, Ogg \& Smith, 2004). Sedimentation resumed in the early Danian, upper part of $\mathrm{P} 1 \mathrm{a}(2)$ amplified by reworking, transport and redeposition of impact spherules and Cretaceous species. 


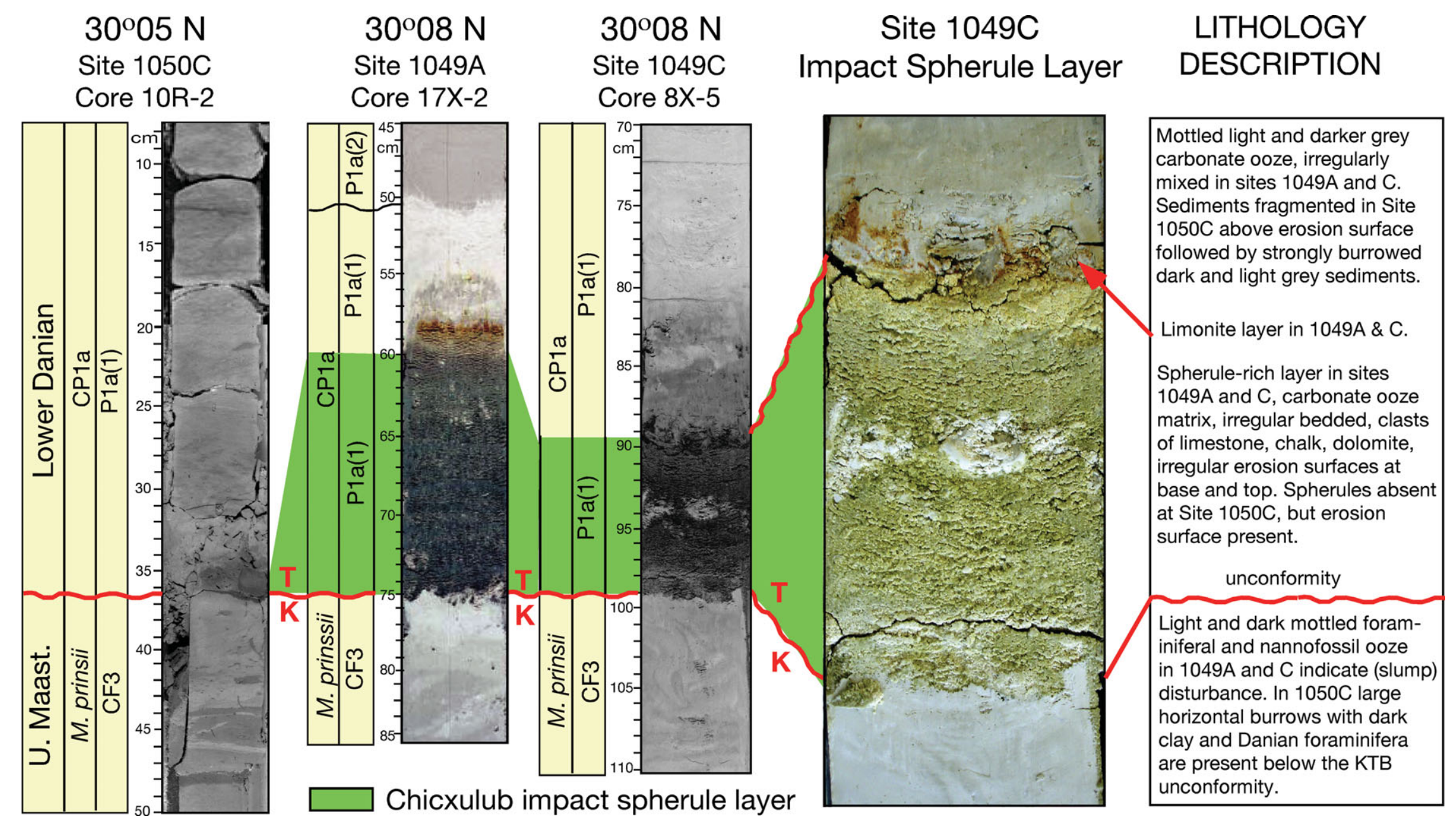

Figure 4. (Colour online) Lithology of Blake Nose ODP Sites 1049A, 1049C and 1050C in the NW Atlantic. Note the distribution of Chicxulub impact spherules above a major unconformity at Sites 1049A and 1049C, but absence at 1050C. The spherule layer is of light green color due to the impact glass alteration as seen in a photo blow-up from 2006 that also shows the irregular surfaces above and below the spherule layer, the limonite layer at the top, and patches of calcareous ooze in the middle. 
At Site 1049A a $2 \mathrm{~mm}$ thin red-brown limonite layer and $8 \mathrm{~cm}$ thick white ooze overlie the spherule layer followed by grey carbonate ooze. At Site 1049C, the limonite layer is also present but discontinuous and white ooze is present in the middle of the spherule layer. Above the limonite layer the $8 \mathrm{~cm}$ dark and light grey ooze is strongly mottled and bioturbated, followed by light grey ooze. At Site 1050C the KTB transition consists of dark and light grey burrowed ooze with some large horizontal burrows infilled with grey ooze that contains rare Danian species below the KTB (Fig. 4). An erosional surface and darker grey layer is correlative with the spherule layer.

Upper Maastrichtian faunal assemblages at all three sites are diverse, abundant and well preserved but lack Plummerita hantkeninoides, the zone CF1 index species for the topmost Maastrichtian (Figs 5-7). However, the presence of Gansserina gansseri (and G. wiedenmayeri in Site 1050C) and Pseudoguembelina hariaensis mark this interval as zone CF3 (Abramovich et al. 2010). Micula prinsii was reported from a short interval below the spherule layer (Norris, Huber \& SelfTrail, 1999), which is consistent with the upper part of zone CF3 (Fig. 2). This indicates a major hiatus that spans Maastrichtian zones CF1 and CF2 $(\sim 280 \mathrm{ka}$, time scale of Gradstein, Ogg \& Smith, 2004; Fig. 2).

\section{5.b.1. Impact spherule layer with early Danian species}

The spherule-rich layer above the KTB unconformity at Sites $1049 \mathrm{~A}$ and $1049 \mathrm{C}$ is $15 \mathrm{~cm}$ and $10 \mathrm{~cm}$ thick, respectively (Fig. 4). Reworked Cretaceous species are common (Figs 5, 6) along with shallow and deepwater benthic foraminifera that indicate reworking and transport of shallow water sediments into the basin (Alegret \& Thomas, 2004). We also observed a dominance of large and thick-shelled species with variable preservation, including discoloration, abrasion and broken shells, and low abundance of small species, all of which indicate reworking and transport. On a quantitative basis $83-95 \%(>63 \mu \mathrm{m})$ of the Maastrichtian species are reworked in the spherule layer and $5-17 \%$ are small Danian species.

The relative abundance of Danian species was calculated based on the $63-100 \mu \mathrm{m}$ size fraction from the spherule layer (Figs 5,6). The presence of diverse assemblages (12 species), including $P$. eugubina and $P$. longiapertura, but absence of $P$. pseudobulloides and/or S. triloculinoides indicates a subzone $\mathrm{P} 1 \mathrm{a}(1)$ assemblage in the spherule layer with the lower part of this subzone and zone P0 missing. A similar Danian assemblage is present in the $8 \mathrm{~cm}$ above the spherule layer at Site 1049A and in the $20 \mathrm{~cm}$ above the spherule layer at Site 1049C, whereas the abundance of reworked Cretaceous species rapidly decreases to $<10 \%$ (Figs 5, 6). The first appearances P. pseudobulloides, S. triloculinoides and the sharp increase in Chiloguembelina morsei and Guembelitria species $8 \mathrm{~cm}$ and $20 \mathrm{~cm}$ above the spherule layer at Sites 1049A and 1049C marks a hiatus between P1a(1) and $\mathrm{P} 1 \mathrm{a}(2)$. At both sites $\mathrm{P} 1 \mathrm{a}(2)$ is dominated by two opportunistic species, C. morsei and G. cretacea, that indicate increased environmental stress. Reworked Cretaceous species are still present but rare $(<2 \%)$.

At Site $1050 \mathrm{C}$ the comparable P1a(1) and P1a(2) assemblages spans the $60 \mathrm{~cm}$ above the KTB unconformity. Reworked species are very rare (Fig. 7). The basal Danian sample is dominated by $P$. eugubina (50\%), which indicates that zone P0 and the lower part of $\mathrm{P} 1 \mathrm{a}(1)$ is missing along with zones CF1 and CF2 ( 400 ka). Subzone P1a(1) is dominated by $P$. eugubina (55-64 \%) with common Eoglobigerina edita and variable presence of seven other Danian species (Fig. 7). The P1a(1)-P1a(2) boundary is marked by a sharp decrease in P. eugubina, concurrent increase in Guembelitria spp. and Chiloguembelina morsei, first appearances of $P$. pseudobulloides and P. taurica. For the next $30 \mathrm{~cm} P$. eugubina and $E$. edita dominate along with $C$. morsey. At the top of this interval $E$. edita becomes rare and P. eugubina disappears, which marks the P1a-P1b boundary. At this interval the sudden disappearance of P. eugubina, decrease in E. edita, sudden increase (to 35-40\%) in Guembelitria spp. and coincident drop in $\delta^{13} \mathrm{C}$ values by nearly $1 \%$, suggests another hiatus. During zone P1b Guembelitria spp. and C. morsei dominate with little change.

Comparison of Sites 1049A, 1049C and 1050C reveals both similarities in faunal assemblages and differences in relative abundances of species populations. The latter are primarily due to variable erosion at the KTB and P1a(1)-P1a(2) hiatuses. In zone P1b all sections show the same faunal assemblages dominated by Guembelitria sp. and Chiloguembelina morsei. Carbon isotope signals also reflect great similarities among these sequences and each hiatus is marked by abrupt shifts in $\delta^{13} \mathrm{C}$ values (see Section 6).

\section{5.c. Caribbean ODP Sites 999B and 1001B}

ODP Sites 1001A and B were drilled $30 \mathrm{~m}$ apart on the Hess Escarpment (lower Nicaragua Rise, $15^{\circ} 45.427^{\prime} \mathrm{N}, 74^{\circ} 54.627^{\prime} \mathrm{W}$ ) at depth of $3259 \mathrm{~m}$ (Fig. 1). The KTB transition was recovered at Site 1001B, core 18R-5 (Sigurdsson et al. 1997). Maastrichtian sediments consist of light grey mottled, burrowed limestone, which in the shipboard photo is speckled with dark flakes from the overlying claystone, but not in the archive core photographed in 2006 (Fig. 8). This limestone contains common Heterohelix globulosa and Ruguglobigerina rugosa but all other species are rare. This low diversity assemblage is partly due to poor preservation and thin-section identification. However, the rarity of globotruncanids, which are more dissolution and break-resistant, and absence of upper Maastrichtian index species indicates a lower upper Maastrichtian zone CF5 age in agreement with the age previously assigned as base Abathomphalus mayaroensis (Sigurdsson et al. 1997). This indicates a major KTB hiatus with all or most of the upper Maastrichtian missing (zones CF1-CF4; Fig. 2). 


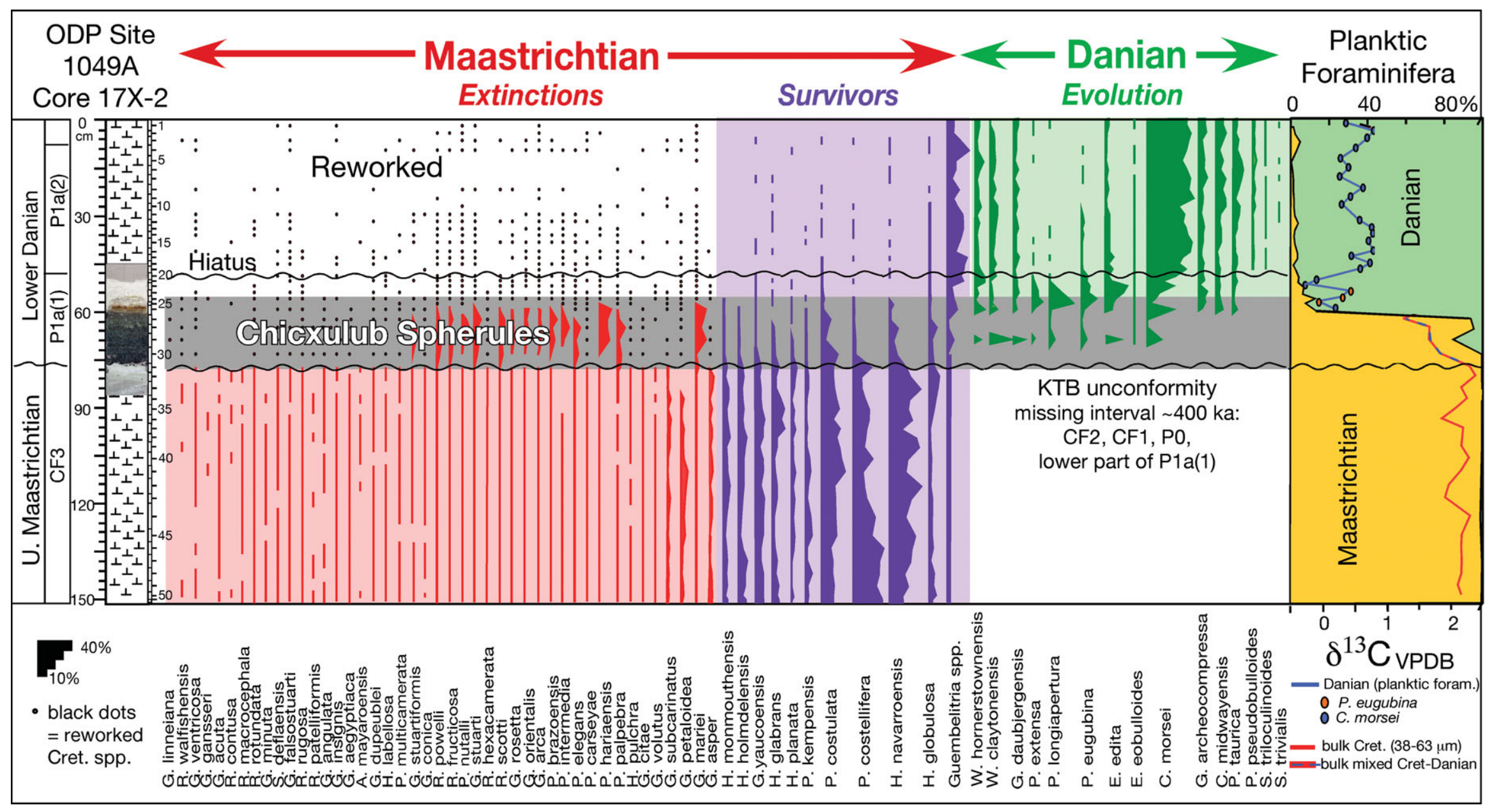

Figure 5. (Colour online) Biostratigraphy and relative species abundances of planktic foraminifera $(>63 \mu \mathrm{m})$ and $\delta^{13} \mathrm{C}$ values at Site $1049 \mathrm{~A}$. An unconformity at the base of the spherule layer spans most of the early Danian subzone P1a(1), P0 and late Maastrichtian zones CF1 and CF2 for a total of about 400 ka. The spherule layer contains common early Danian subzone P1a(1) species along with abundant reworked Cretaceous species. The $\delta^{13} \mathrm{C}$ curve shows Maastrichtian values below the unconformity and a $2 \%$ o shift in the spherule layer (based on Danian species). Reworked Cretaceous species drop to $<10 \%$ above the spherule layer. A short hiatus at the $\mathrm{P} 1 \mathrm{a}(1)-\mathrm{P} 1 \mathrm{a}(2)$ boundary is marked by a $1 \%$ o positive shift marking the initial (temporary) increase in primary productivity after the KTB mass extinction. 


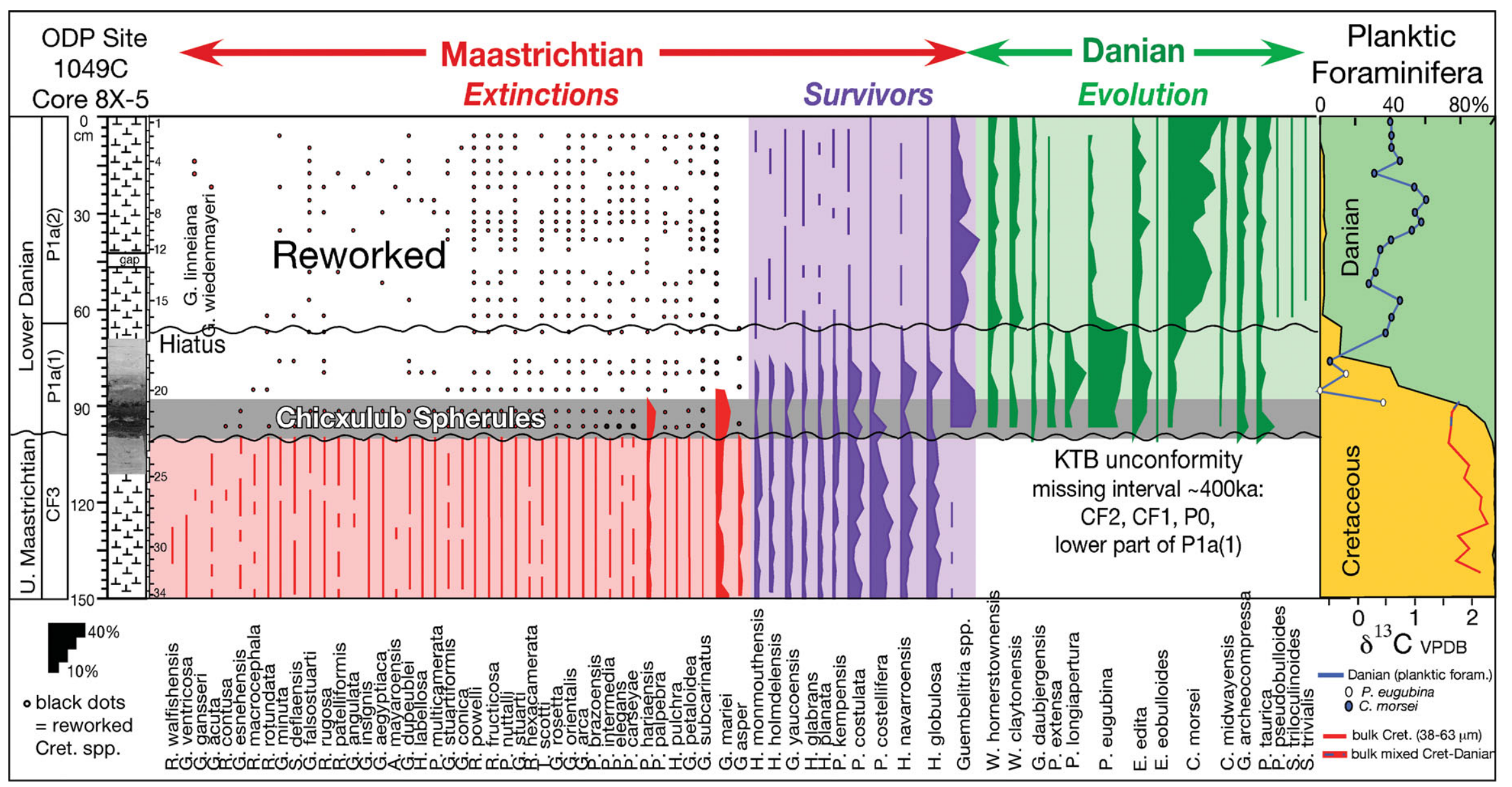

Figure 6. (Colour online) Biostratigraphy and relative species abundances of planktic foraminifera $(>63 \mu \mathrm{m})$ and $\delta^{13} \mathrm{C}$ values at Site $1049 \mathrm{C}$ show a similar pattern to Site $1049 \mathrm{~A}$, although with some variability due to better preservation notably in the higher abundance of Danian species in the spherule layer. The KTB unconformity spans the same interval as at Site $1049 \mathrm{~A}$ but reworked Cretaceous species decrease more gradually in the early Danian. $\delta^{13} \mathrm{C}$ values decrease by $2.5 \%$ across the KTB unconformity followed by the initial early Danian recovery of $1 \% o$ at the P1a(1)-P1a(2) boundary marked by a hiatus. 


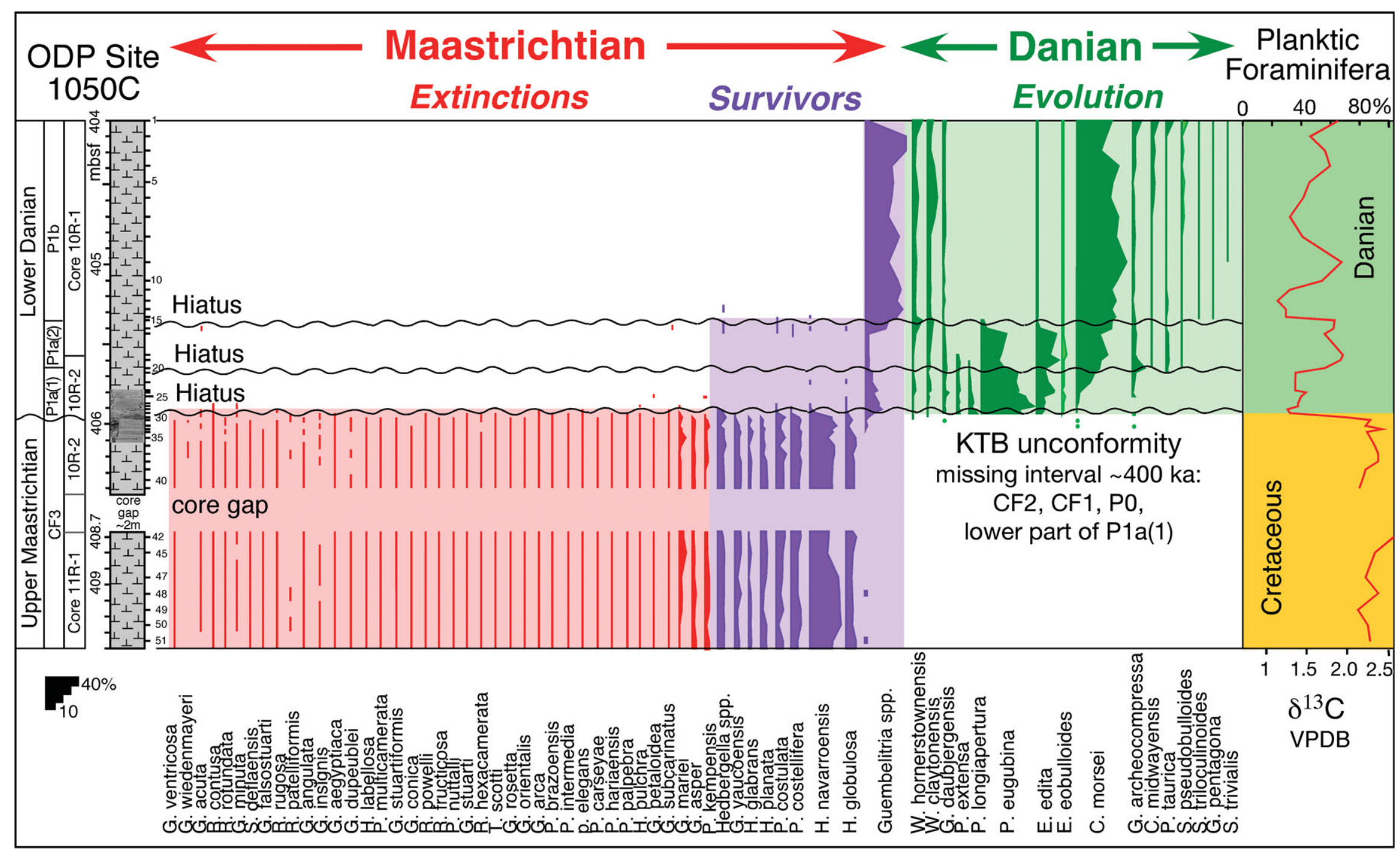

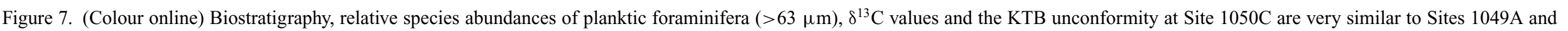
$1049 \mathrm{C}$, which are located $300 \mathrm{~m}$ downslope and at a distance of $10 \mathrm{~km}$. However, no impact spherule layer is present and reworked Cretaceous species are rare. $\delta^{13} \mathrm{C}$ values (bulk rock) show the negative shift across the KTB unconformity, the temporary recovery marked by a short hiatus at the P1a(1)-P1a(2) boundary and the negative shift at the P1a(2)-P1b hiatus. 


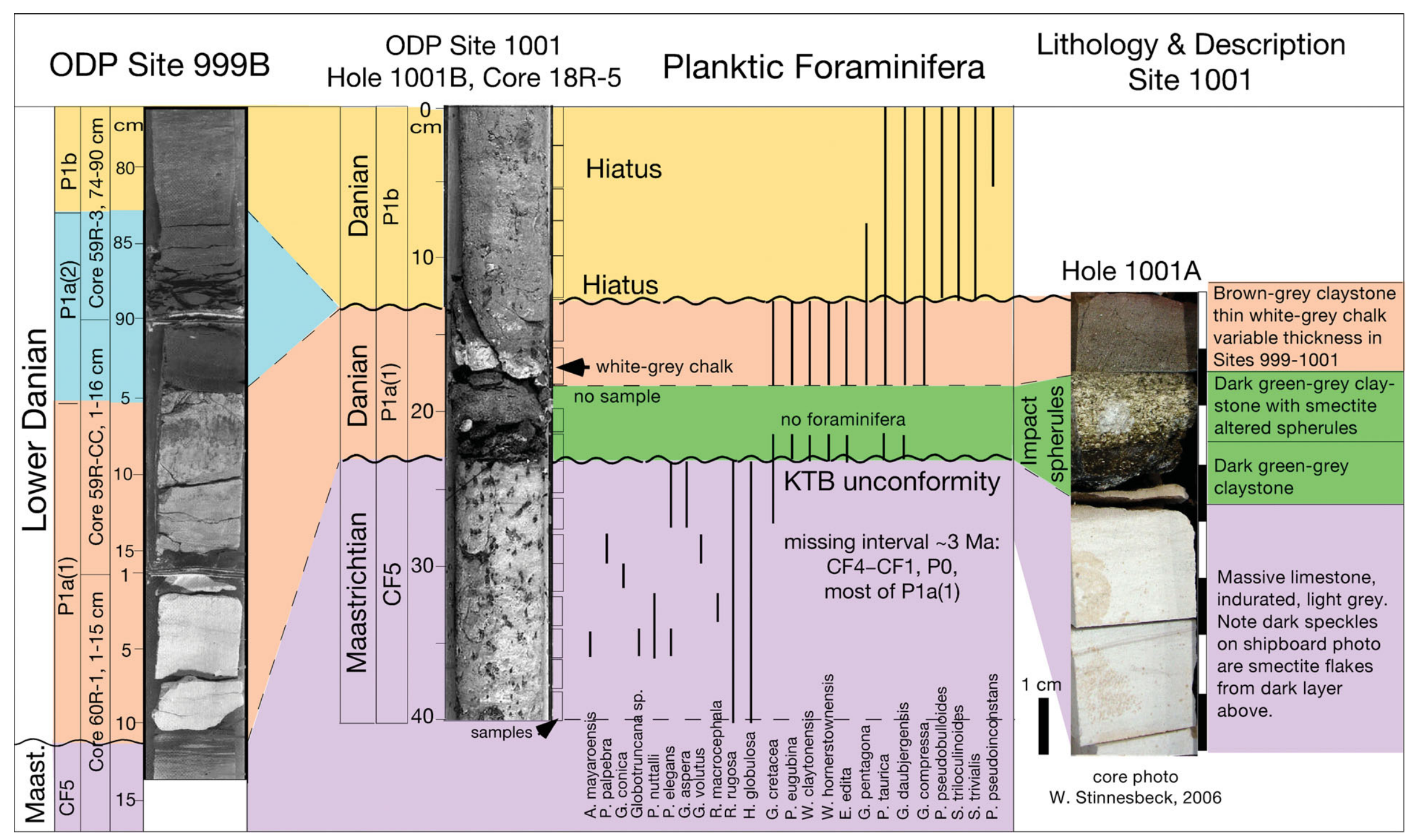

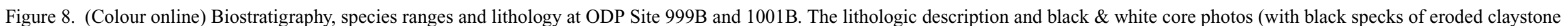

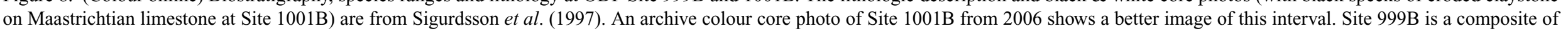

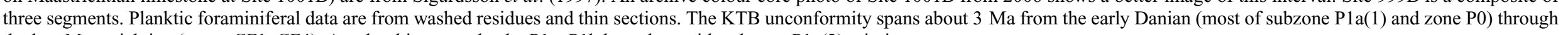
the late Maastrichtian (zones CF1-CF4). Another hiatus marks the P1a-P1b boundary with subzone P1a(2) missing. 
Above the unconformity is a $1.5-2.0 \mathrm{~cm}$ thick greengrey claystone with impact spherules altered to smectite and containing a lower Danian subzone P1a(1) assemblage (Fig. 8). The overlying $1.5-2.0 \mathrm{~cm}$ thick dark green-grey claystone contains abundant clay-altered spherule debris but no foraminifera. No sample was available for this study from the overlying $1.5 \mathrm{~cm}$ thick brown-grey claystone. Above this claystone at Site $1001 \mathrm{~B}$ is a $2 \mathrm{~cm}$ thick white-grey chalk, which is not observed at Hole 1001A but well developed $(\sim 10 \mathrm{~cm})$ at Site 999B, where it overlies a white limestone (Fig. 8). The $3-5 \mathrm{~cm}$ thick overlying claystone at holes 1001A and $\mathrm{B}$ contains a more diverse subzone $\mathrm{P} 1 \mathrm{a}(1)$ assemblage of nine species (Fig. 8).

Sigurdsson et al. (1997) reported the first appearance of lower Danian species in this white-grey chalk of Hole 1001B. In the overlying claystone the abrupt disappearance of the early Danian species (P. eugubina, E. edita, $W$. claytonensis and $W$. hornerstownensis) and simultaneous first appearance of $S$. triloculinoides. $P$. pseudobulloides and $S$. trivialis (core 18R-5, $14 \mathrm{~cm}$ ) marks a hiatus between $\mathrm{P} 1 \mathrm{a}(1)$ and $\mathrm{P} 1 \mathrm{~b}$ with subzone P1a(2) missing. This data suggests a similar KTB and early Danian erosion pattern to Bass River and Blake Nose with impact spherules reworked into early Danian subzone P1a(1). However, erosion of Maastrichtian sediments at the KTB unconformity is more extensive spanning zones CF1-CF4 ( 3 Ma; Figs 2, 8).

ODP Site 999B was drilled on Kogi Rise, Colombian Basin $\left(12^{\circ} 44.639^{\prime} \mathrm{N}, 78^{\circ} 44.360^{\prime} \mathrm{W}\right)$ at $2828 \mathrm{~m}$ depth (Fig. 1). Recovery across the KTB was incomplete. Sigurdsson et al. (1997) assembled a composite section based on three segments (59R-3, 59R-CC and the top of core $60 \mathrm{R}-1$ ) and placed the KTB at the base of a white limestone (60R-1, $1 \mathrm{~cm}$ ), correlative with the whitegrey chalk at Site 1001B (Fig. 8). No spherules are present and it was suggested they may have been lost in the drilling process.

Samples were obtained from the KTB transition. Preservation of foraminifera is poor due to dissolution, and the biostratigraphy was determined from species in washed residues and from thin sections. The Maastrichtian limestone at Site 999B (up to 60R-1, 15-18 cm) contains the same impoverished assemblage indicative of zone CF5 as at Site 1001B, which is indicative of the lower upper Maastrichtian (Fig. 2). Sigurdsson et al. (1997, p. 154) suggested an upper Maastrichtian age of CC26 (Nephrolithus frequens) or underlying CC25 zone (Arkhangelskiella cymbiformis). They concluded: 'it is not possible to determine whether the K/T boundary at Site 999 is complete from a nannofossil biostratigraphic viewpoint.'

Between the grey Maastrichtian limestone and overlying white limestone is a $1-2 \mathrm{~cm}$ thick grey claystone with rare Maastrichtian species but abundant Guembelitria cretacea and few W. hornerstownensis, $G$. daubjergensis and P. eugubina, which indicate deposition in the lower Danian subzone Pla(1). The overlying $10 \mathrm{~cm}$ thick white limestone also contains a lower Danian subzone P1a(1) assemblage, similar to the thin grey-white chalk at Site 1001B (Fig. 8). Based on this data we place the KTB unconformity between the Maastrichtian limestone and grey claystone at the first Danian assemblage.

The white-grey limestone (59R-CC, 1-15 cm) above the white limestone contains rare and poorly preserved Danian species. Above this layer is a darker grey clayrich marl that contains a diverse lower Danian subzone $\mathrm{P} 1 \mathrm{a}(2)$ assemblage (G. cretacea, Eoglobigerina edita, P. eugubina, Woodringina hornerstownensis, $W$. claytonensis, Globoconusa daubjergensis, Praemurica taurica, S. triloculinoides, P. pseudobulloides, G. compressa), which is missing at Site 1001B (Fig. 8). However, the overlying zone P1b assemblage (59R-3, $74-82 \mathrm{~cm}$ ) is present in both sites. These data indicate a more expanded sediment record across the KTB at Site 999B. However, because this record was pieced together from three different core segments the true sediment record remains uncertain.

\subsection{Demerara Rise ODP Site 1259B}

ODP Site 1259 was drilled on Demerara Rise $\left(9^{\circ} 18.048^{\prime} \mathrm{N}, 54^{\circ} 11.945^{\prime} \mathrm{W}\right)$ at a water depth of $2354 \mathrm{~m}$ (Fig. 1). A $2 \mathrm{~cm}$ thick impact spherule layer was recovered at Sites 1259B and 1259C (as well as Sites 1258A, 1260A, Shipboard Scientific Party, 2004; MacLeod et al. 2007; Schulte et al. 2009). Most KTB studies have focused on Sites 1259B and 1259C. We obtained samples from Site 1259B where the spherule layer is in core $13-1,47-49 \mathrm{~cm} ; 31$ samples were analyzed for this report. Sediments below the spherule layer consist of mottled, bioturbated marly chalk with a relatively sharp upper contact. The spherule layer is graded and thin white chalk layers are present at the base and top, similar to Site 1001B. Danian sediments consist of strongly mottled, bioturbated light and darker grey clayey chalk.

Preservation of planktic foraminifera is good for the Danian and moderate in the Maastrichtian with dissolution effects (thin walls, holes in test chambers). The marly chalk below the spherule layer contains a diverse late Maastrichtian planktic foraminiferal assemblage, including rare Plummerita hantkeninoides, the index species for zone CF1 (Fig. 9). Cretaceous assemblages in the $>63 \mu \mathrm{m}$ size fraction are dominated by small biserial species (Pseudoguembelina costulata, Heterohelix planata, H. navarroensis), whereas Guembelitria cretacea is common in the smaller size fraction (36-63 mm). Rare Danian species were obtained from the $10 \mathrm{~cm}$ thick bioturbated light and dark grey clay below the KTB unconformity and spherule layer; these specimens are likely due to burrowing from the overlying Danian.

One sample was obtained from the spherule layer. Upper Maastrichtian planktic foraminifera are common in the $>63 \mu \mathrm{m}$ size fraction, and small Danian species are common in the $36-63 \mu \mathrm{m}$ size fraction where Guembelitria species dominate (83-96\%) in the spherule layer and up to $8 \mathrm{~cm}$ above it (Fig. 9). 


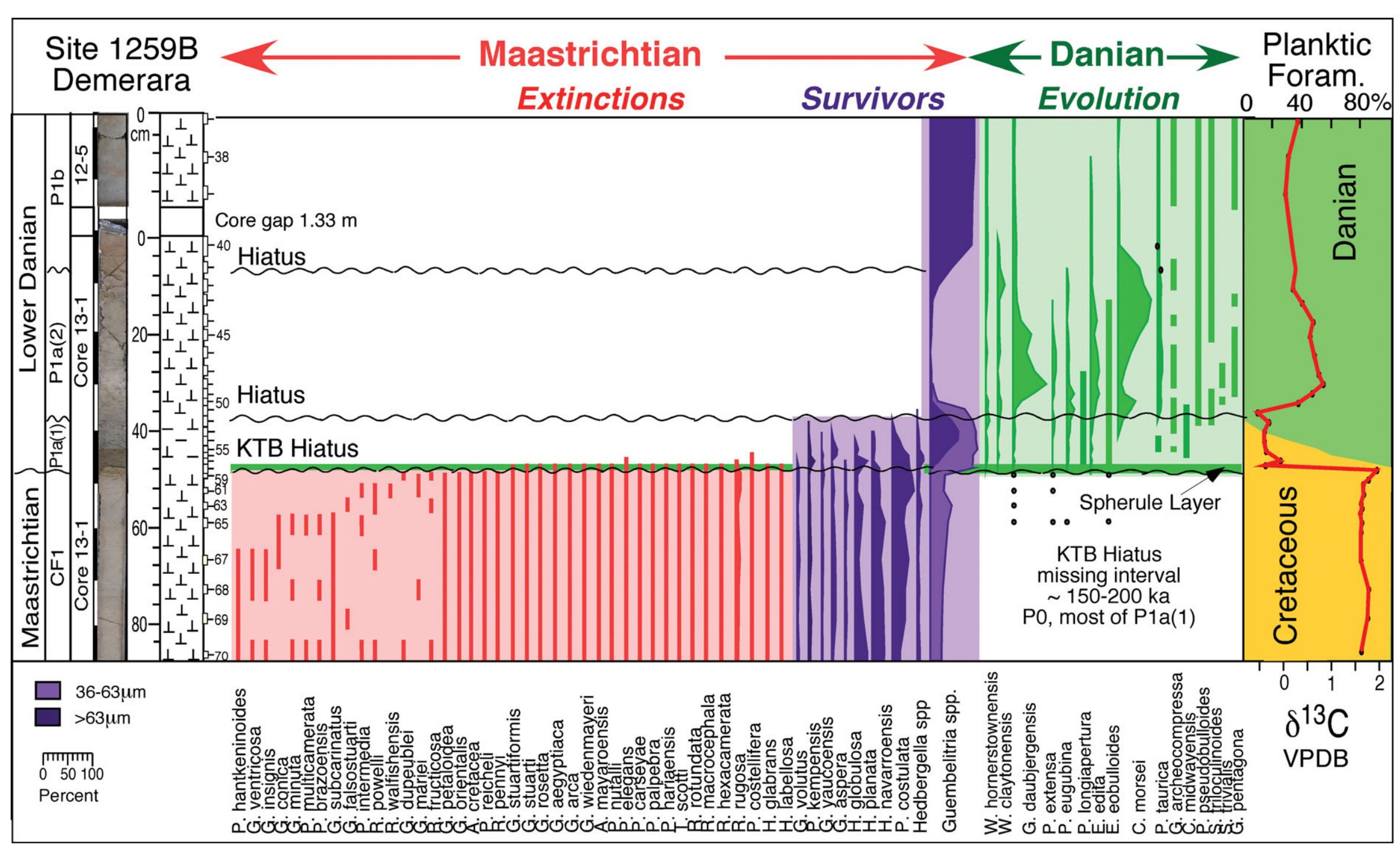

Figure 9. (Colour online) Biostratigraphy, relative species abundances of planktic foraminifera ( $>63 \mu \mathrm{m}), \delta^{13} \mathrm{C}$ values and the KTB unconformity at SW Atlantic Site 1259B. Note the species pattern is similar to NW Atlantic sites although Cretaceous species (mainly KTB survivors) are restricted to the first $10 \mathrm{~cm}$ above the unconformity and base of the $2 \mathrm{~cm}$ spherule layer. A diverse Pla(1) assemblage of early Danian species is present in the spherule layer and dominates the small size fraction (36-63 mm) with $>85 \%$ Guembelitria species. Hiatuses are present at the P1a(1)-P1a(2) and P1a(2)-P1b boundaries marked by abrupt species abundance changes. 
The presence of P. eugubina, G. daubjergensis, $W$. hornerstownensis, W. claytonensis and E. eobulloides in the spherule layer and the $8 \mathrm{~cm}$ above indicate subzone P1a(1). The first P. pseudobulloides and Subbotina triloculinoides appear in sample 13-1, at $37-39 \mathrm{~cm}$, and mark the P1a(1)-P1a(2) subzone boundary just $8 \mathrm{~cm}$ above the spherule layer. A short hiatus is present at this level as indicated by the abrupt decrease in Guembelitria spp. and correlative abrupt recovery in $\delta^{13} \mathrm{C}$ values. Above this hiatus the rapid increase in Globoconusa daubjergensis followed by C. morsei and the extinction of P. eugubina $37 \mathrm{~cm}$ above the spherule layer marks the $\mathrm{P} 1 \mathrm{a}(2)-\mathrm{P} 1 \mathrm{~b}$ boundary. A short hiatus may also be present at this level as indicated by the abrupt assemblage change to dominant Guembelitria spp. (85-90 \%) and abrupt decrease in C. morsei.

These data suggest a relatively complete latest Maastrichtian (zone CF1 index species present) but a short KTB hiatus with most of the Danian subzone $\mathrm{P} 1 \mathrm{a}(1)$ and underlying zone $\mathrm{P} 0$ missing. In addition, a short hiatuses is present at the $\mathrm{P} 1 \mathrm{a}(1)-\mathrm{P} 1 \mathrm{a}(2)$ boundary and probably $\mathrm{P} 1 \mathrm{a}(2)-\mathrm{P} 1 \mathrm{~b}$ boundary. Similar early Danian erosion and redeposition patterns are observed at Sites 999B, 1001B, 1049A, 1049C, 1050C and Bass River, although the extent of erosion varies at each location. This is indicated by the variable species abundance patterns between sites although in the same biozones $\mathrm{P} 1 \mathrm{a}(1), \mathrm{P} 1 \mathrm{a}(2)$ and $\mathrm{P} 1 \mathrm{~b}$ and presence of similar $\delta^{13} \mathrm{C}$ signals. For example, at Site 1259B $P$. eugubina is relatively rare, subzone $\mathrm{P} 1 \mathrm{a}(1)$ is only $8 \mathrm{~cm}$ thick, dominated by Guembelitria spp., but with a diverse (14 species) assemblage that indicates an upper $\mathrm{P} 1 \mathrm{a}(1)$ interval not observed in the other sections. Subzone $\mathrm{P} 1 \mathrm{a}(2)$ is dominated by C. morsei, similar to all other sites, but fewer Guembelitria spp. Zone P1b differs in its great abundance of Guembelitria ( $90 \%)$ and low abundance of all other species. The difference here is likely due to the core gap of $1.33 \mathrm{~m}$ where a critical part of the faunal transition is missing (Fig. 9).

\section{Stable isotope stratigraphy}

One of the characteristic KTB markers is a $2-3 \%$ o negative $\delta^{13} \mathrm{C}$ shift at the base of the Danian, which reflects the productivity crash after the mass extinction. Similarly, the $\delta^{13} \mathrm{C}$ variations in the early Danian mark the delayed marine recovery and setbacks in the aftermath of the mass extinction. Therefore, carbon isotope stratigraphy, coupled with planktic foraminiferal biostratigraphy, is an excellent and independent method for determining the completeness of the sediment record. No such high-resolution data is published to date for any of the sites analyzed for this study. For Blake Nose (Sites 1049A, 1049B and 1050) and Demerara Site 1259B we analyzed the bulk rock fine fraction $(36-63 \mu \mathrm{m})$, which consists primarily of nannoplankton and small planktic foraminifera and is generally a good indicator of primary productivity (Zachos, Arthur \& Dean, 1989; Schrag, DePaolo \& Richter, 1995). For the Maastrichtian, $\delta^{13} \mathrm{C}$ values vary between 1.8 and $2.2 \%$, except for Site $1050 \mathrm{C}$ which is slightly heavier (2.2-2.4\%o; Fig. 10). These values are comparable to those observed in open marine environments, such as South Atlantic Site $525 \mathrm{~A}(\mathrm{Li}$ $\&$ Keller, 1998a). No significant changes in $\delta^{13} \mathrm{C}$ are apparent for the intervals of CF3 and CF1 analyzed below the KTB unconformity.

At Sites 1050C and 1259B, the KTB unconformity is marked by a sudden drop in $\delta^{13} \mathrm{C}$ values of $1.2 \%$ and $2.0 \%$, respectively. At Sites 1049A and 1049C the bulk fine fraction yielded a gradual decrease in $\delta^{13} \mathrm{C}$ values well into the early Danian because of the abundance of reworked Cretaceous species (Figs 5, 6). We obtained an uncompromised lower Danian record from monospecific samples of the Danian species $P$. eugubina and C. morsei. In some samples both species were analyzed and the interspecies variation is less than $0.3 \%$. Preservation of Danian foraminiferal tests is very good and shell calcite is not recrystallized, but there is minor calcite overgrowth on shell surfaces, which may account for some of the interspecies variation. About 200-300 specimens were picked per sample for stable isotope analysis. In the lower and middle part of the spherule layer only about 100 150 specimens per species could be obtained in the available sample (in addition to the quantitative counts that are archived) and this quantity turned out to be insufficient for reliable isotope signals. Nevertheless, in the lower Danian subzone P1a(1), including the top of the spherule layer, the $\delta^{13} \mathrm{C}$ values of Danian species reached lows of $-0.5 \%$ o suggesting a drop of about $2 \%$ across the KTB, similar to Site 1259B (Fig. 10). These values are characteristic for the lower Danian above the impact spherule layer in Haiti and the equivalent P1a(1) interval in Tunisia (Keller \& Lindinger, 1989; Keller et al. 2001; Stueben et al. 2002).

Major variations in $\delta^{13} \mathrm{C}$ signals through the early Danian can be correlated despite the frequent hiatuses and variable erosion identified from planktic foraminiferal biostratigraphy and species abundance patterns. The lowest $\delta^{13} \mathrm{C}$ values are known from the early Danian in the aftermath of the mass extinction. In all sites analyzed, at least part of this interval is recorded in fine fraction and planktic foraminifera of subzone $\mathrm{P} 1 \mathrm{a}(1)$ that includes the spherule layer (Fig. 10). An abrupt positive shift of about 1\%o coincides with the $\mathrm{P} 1 \mathrm{a}(1)-\mathrm{P} 1 \mathrm{a}(2)$ hiatus. In $\mathrm{P} 1 \mathrm{a}(2)$, $\delta^{13} \mathrm{C}$ signals remain relatively high but do not reach pre-KTB values. The $\mathrm{P} 1 \mathrm{a}(2)$ record is fragmented in the sites analyzed due to variable erosion similar to $\mathrm{P} 1 \mathrm{a}(1)$. At Site $1050 \mathrm{C}$ a negative $\delta^{13} \mathrm{C}$ shift at the $\mathrm{P} 1 \mathrm{a}(2)-\mathrm{P} 1 \mathrm{~b}$ boundary marks the hiatus. This shift was not detected at Sites 1049A and 1259B because of the $0.80 \mathrm{~m}$ and $1.33 \mathrm{~m}$ core gaps, respectively.

\section{Discussion}

\section{7.a. KTB unconformity}

A thin impact spherule layer between Maastrichtian and Paleocene sediments in some KTB sequences from the 


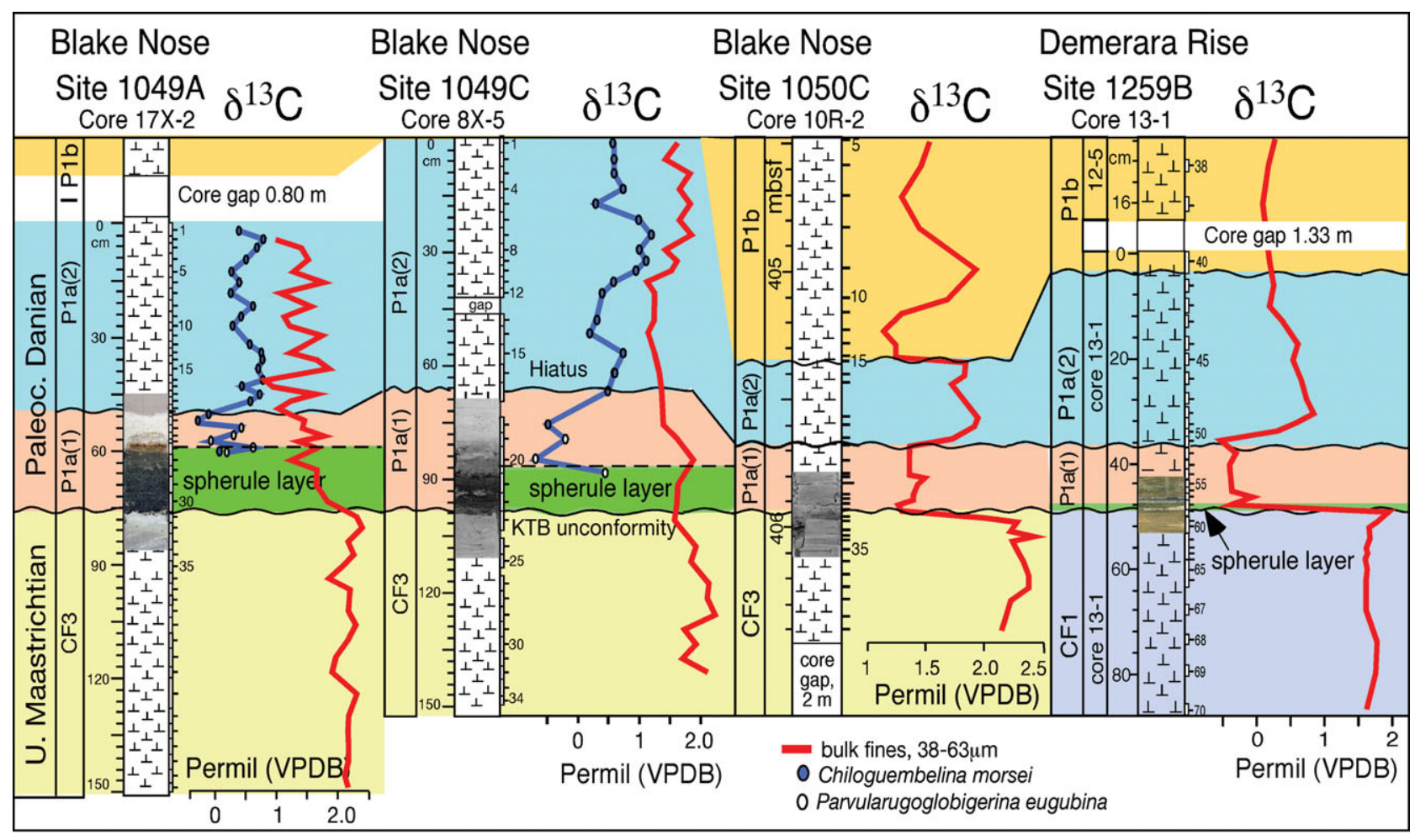

Figure 10. (Colour online) Bulk rock $\delta^{13} \mathrm{C}$ values from the NW to SW Atlantic ODP sites across the KTB transition and impact spherule layer show a 1.5 to $2.5 \%$ negative excursion at Sites $1050 \mathrm{C}$ and 1259B, but not at Sites 1049A and 1049C due to abundant reworked Cretaceous sediments in the spherule layer and above. However, this signal is recovered in monospecific Danian planktic foraminifera. In all sequences $\delta^{13} \mathrm{C}$ in the early Danian subzone $\mathrm{P} 1 \mathrm{a}(1)$ interval record the most negative values. A positive shift of about $1 \%$ at the $\mathrm{P} 1 \mathrm{a}(1)-\mathrm{P} 1 \mathrm{a}(2)$ hiatus marks initial recovery after the mass extinction. Another negative $\delta^{13} \mathrm{C}$ excursion marks the P1a(2)-P1b boundary at Site 1050C; core gaps are present at this interval at Sites 1049A and 1259B.

North Atlantic and Caribbean, is commonly cited as proof that the Chicxulub impact is KTB in age and the sedimentation record complete (e.g. Olsson et al. 1997; Sigurdsson et al. 1997; Norris et al. 1998; Norris, Huber \& Self-Trail, 1999; Martinez-Ruiz et al. 2001; MacLeod et al. 2007; Schulte et al. 2010). Results based on high-resolution biostratigraphy, quantitative faunal analyses and stable isotopes show that far from being complete all seven sections analyzed show a major unconformity across the KTB with variable erosion of Maastrichtian sediments.

The maximum extent of erosion can be estimated based on Paleocene and Maastrichtian sediments above and below the unconformity, respectively. At Bass River, New Jersey, the KTB unconformity spans from the early Danian subzone P1a(2) through to the upper Maastrichtian zones $\mathrm{CF} 1$ and $\mathrm{CF} 2(\sim 620 \mathrm{ka}$; Figs 2, 3), in North Atlantic Sites 1049A, 1049C and $1050 \mathrm{C}$ from $\mathrm{P} 1 \mathrm{a}(1)$ through to $\mathrm{CF} 1$ and $\mathrm{CF} 2(\sim 400 \mathrm{ka}$; Figs 5-7), and in the Caribbean Sites 999B and 1001B from P1a(1) through to zones CF1, CF2, CF3 and CF4 ( $\sim 3 \mathrm{Ma}$; Fig. 8). Only at Demerara Rise Site 1259B is erosion or non-deposition more limited, spanning most of subzone P1a(1) and zone P0 ( 150-200 ka; Fig. 9). The nearby Site 1258A provides some clues to possible erosion at the top of the Maastrichtian. Just below the KTB, Thibault \& Gardin (2006) recorded the abrupt end of the nannofossils Micula murus acme that marks the CF1 warm event. In complete sequences, this global warm event ends with the onset of cooling about 50-100 ka prior to the KTB (Li \& Keller, 1998a; Abramovich \& Keller, 2003; Abramovich et al. 2011), which suggests erosion of the latest Maastrichtian at Site 1258 A and likely at Site 1259B.

We can estimate the missing interval above the KTB based on Danian sediments present within and above the spherule layer. In a complete sequence, biozones $\mathrm{P} 0+\mathrm{P} 1 \mathrm{a}(1)+\mathrm{P} 1 \mathrm{a}(2)$ span $\mathrm{C} 29 \mathrm{R}$ above the KTB, or $380 \mathrm{ka}$ based on Gradstein, Ogg \& Smith, (2004), and half of this is P0 + P1a(1) (Fig. 2). In all sections examined, zone $\mathrm{P} 0$ is absent and $\mathrm{P} 1 \mathrm{a}(1)$ is very reduced (missing at Bass River) with abrupt changes in species abundances and the $\delta^{13} \mathrm{C}$ shift reflecting a hiatus (Figs 5-9). Similarly, subzone $\mathrm{P} 1 \mathrm{a}(2)$ is reduced with abrupt changes in $\delta^{13} \mathrm{C}$ and species abundances marking a hiatus at the P1a(2)-P1b boundary (Figs 2-9).

Early Danian P1a hiatuses have been observed in many sections worldwide (e.g. MacLeod \& Keller, 1991a, b; Keller et al. 2002, 2003a, b; Keller, 2008) and may reflect global climate and sea level changes (Adatte, Keller \& Stinnesbeck, 2002). However, North Atlantic and Caribbean sites differ in the extensive erosion and/or non-deposition in the early Danian (P0$\mathrm{P} 1 \mathrm{a}-\mathrm{P} 1 \mathrm{~b})$ and spanning well into the upper Maastrichtian (CF1-CF2; Fig. 2). We attribute this primarily to tectonic activity in the Caribbean, climate and sea level changes, and intensified current circulation (e.g. Gulf Stream, Keller et al. 1993; Watkins \& Self-Trail, 2005). 


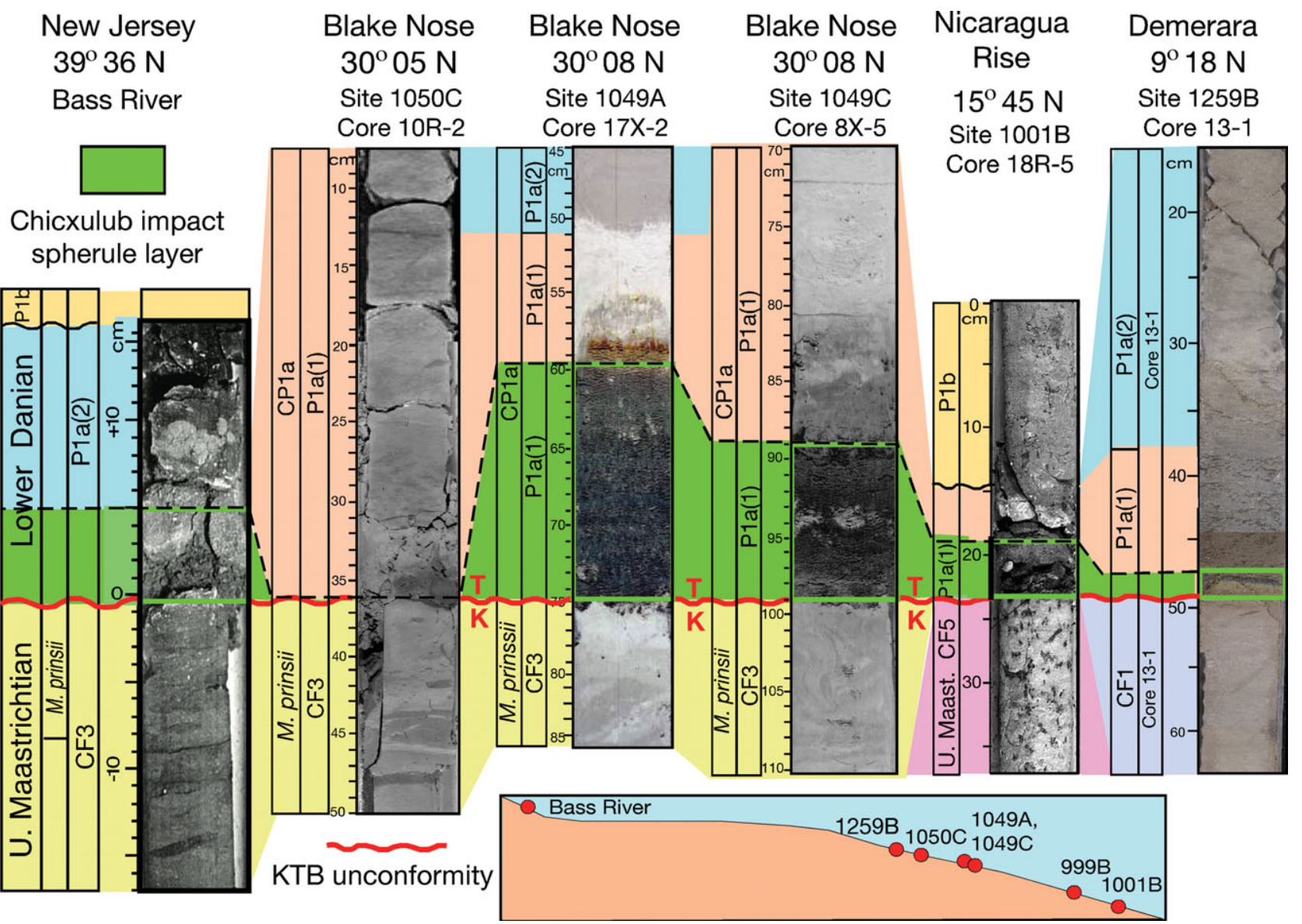

Figure 11. (Colour online) Biostratigraphic and lithostratigraphic correlation of the KTB transition and Chicxulub impact spherules in cores from the NW to SW Atlantic. A major KTB unconformity is present in all sites with the upper Maastrichtian zones CF1 and CF2 missing in the NW Atlantic and zones CF1-CF4 missing on Nicaragua Rise. In the early Danian, zone P0 and most of subzone $\mathrm{P} 1 \mathrm{a}(1)$, or about 150-200 ka, is missing. When sedimentation resumed, impact spherules and Cretaceous species were reworked in subzone P1a(1) at all sites, except at Bass River, New Jersey, where impact spherules are reworked in P1a(2) above the unconformity. A major unconformity is ubiquitous in NW Atlantic and Caribbean sequences (Keller et al. 1993; Bralower, Paull \& Leckie, 1998) and is likely the result of sea level falls and intensified Gulf Stream circulation.

The Chicxulub impact may have contributed mainly via mass wasting of Maastrichtian sediments as suggested by Norris et al. (2000) and Klaus et al. (2000), although these sections do not support this scenario.

\section{7.b. Age and origin of impact spherules}

A KTB age for the Chicxulub impact was assumed based on spherules between Maastrichtian and Danian sediments at the sites investigated (Fig. 11; e.g. Olsson et al. 1997; Sigurdsson et al. 1997; Norris, Huber \& Self-Trail, 1999; MacLeod et al. 2007). There are three key factors that argue against this interpretation: (1) there is a major KTB unconformity in all sequences, except for Site 1259B; (2) the spherule-rich sediments contain common reworked Maastrichtian species and shallow water benthic foraminifera (Alegret \& Thomas, 2004), which argues for erosion and redeposition, and (3) the spherule layer contains a diverse early Danian $\mathrm{P} 1 \mathrm{a}$ (1) species assemblage, which argues for deposition during the early Danian, well after the mass extinction and evolution of the first Danian species. Earlier studies reported the first Danian species above the spherule layer and thereby justified placing the KTB at its base. It is possible that the early Danian assemblages were not observed because of their small size.

One might argue that the Danian species in the spherule layer are an artifact of bioturbation or leaking of sediments into the more porous spherule layer. Some bioturbation is clearly evident in the lithology of Sites 1049A, 1049C, 1050C (Fig. 4). Similarly at Site 1259B, rare Danian species were observed in burrows below the KTB unconformity (Fig. 9), contrary to Schulte et al. (2009, p. 1185) who noted that 'burrows or other signs of bioturbation are totally lacking.' Although bioturbation may account for some Danian specimens in the spherule layer, this could not account for the diverse assemblage with hundreds of specimens and similar species abundances and diversity as in assemblages above the spherule layer.

The presence of these Danian assemblages in the spherule layer above the unconformity indicate that sedimentation resumed in the upper subzone P1a(1) about 150-200 ka after the KTB mass extinction, except for Bass River where the age is $\mathrm{P} 1 \mathrm{a}(2)$. This indicates that the spherules are eroded, transported and 
redeposited long after the Chicxulub impact. Because the normal early Danian evolutionary pattern is present, except for the missing basal Danian, we can assume that the Danian fauna represents in situ deposition but with added downslope transport of spherule-rich reworked debris and Maastrichtian foraminifera. The absence of spherules in Site 1050C can be explained by its distant location from the submarine channel that transported debris to Sites 1049. Similar reworking of shallow water sediments and spherules, transport and redeposition into deeper waters is also observed in NE Mexico sections and Site 1259 (Alegret, Molina \& Thomas, 2001; Alegret et al. 2002; Alegret \& Thomas, 2004). Based on the results from this study, the spherules in lower Danian sediments must be reworked from an older primary deposit. Reworked impact spherules have previously been observed in Danian sediments from Haiti, Cuba, Belize, Guatemala and southern Mexico (Keller et al. 2001, 2003a; Alegret et al. 2005; Arenillas et al. 2006; Keller, 2008).

The strongest case for primary spherule deposition precisely at the KTB, and hence precise KTB age for the Chicxulub impact, was made for Demerara Site 1259B by Schulte et al. (2009) based on geochemical and mineralogical analyses. Based on their results (p. 1185) they divided the $1.5-2 \mathrm{~cm}$ thick spherule layer into two distinct parts: the upper $0.5-0.7 \mathrm{~mm}$ with (1) 'locally enhanced $\mathrm{Si}, \mathrm{Al}$, and $\mathrm{K}$ contents due to the presence of silicic detritus (i.e. quartz, feldspars, mica), and (2) local $\mathrm{Ca}$ - and $\mathrm{Mg}$-enrichment, indicating the occurrence of calcite and dolomite clasts.' Moreover, they observed a strong negative $\mathrm{Nd}$ anomaly, which indicates uptake from contemporaneous ocean water during alteration, which in turn implies a long term residence time for the spherules in seawater. Schulte et al. (2009, p. 1200) concluded that the $\mathrm{Nd}$ isotope systematics 'is best explained by uptake of neodymium from the ocean during the alteration process; this $\mathrm{Nd}$ directly reflects fluviatile input from the rather old crustal material in the South American hinterland.' Rather than primary deposition at the time of the Chicxulub impact as argued by Schulte et al. (2009), these data indicate redeposition of spherules and other detritus that originally accumulated somewhere close to the Guyana craton. This interpretation is consistent with the biostratigraphic results of this study.

\section{7.c. KTB unconformity and the Chicxulub impact}

One might argue that the KTB unconformity is unusual and must have an extraordinary cause, such as the Chicxulub impact (e.g. Bralower, Paull \& Leckie, 1998; Arenillas et al. 2006; Schulte et al. 2010). However, this unconformity is not unique in the NW-SW Atlantic, Caribbean and Gulf of Mexico, where major unconformities are the norm throughout the Cretaceous (Keller et al. 1993), though most workers have concentrated on the KTB (Bralower, Paull \& Leckie, 1998; Watkins \& Self-Trail, 2005). Shorter pulses of erosion in the early Danian, as documented in this study, are also widespread (MacLeod \& Keller, 1991a, $b$; Keller et al. 2003b; this study). Moreover, impact spherules and frequently small iridium anomalies are present above the KTB unconformity in early Danian P1a sediments in Cuba and southern Mexico (Alegret et al. 2005; Arenillas et al. 2006), in Haiti, Belize, and Guatemala (Keller et al. 2001, 2003a; Keller, 2008) and in the Caribbean and N. Atlantic (this study). Impact spherules are abundant and restricted to the latest Maastrichtian zone CF1 ( 130-150 ka below KTB) in NE Mexico and Texas where KTB sequences are more complete. Their absence below the KTB in the Atlantic, Caribbean, Gulf of Mexico, southern Mexico, Haiti, Belize and Guatemala is likely due to erosion linked to intensified current circulation and the impact (Keller et al. 1993; Watkins and Self-Trail, 2005).

Bralower, Paull \& Leckie, (1998) attributed any reworked microfossils, impact derived materials, lithic fragments and unconformities in the Caribbean and Gulf of Mexico to the Chicxulub impact and proposed that such deposits (labeled impact cocktail) are a reliable way to identify the KTB. All of the sections discussed in their paper show faunal and hiatus patterns similar to the Atlantic and Caribbean sections of this study where impact spherules are reworked in the early Danian and provide no evidence for a KTB age for the Chicxulub impact. Thus, caution must be exercised in interpreting iridium anomalies and impact spherules as KTB age markers for the Chicxulub impact, limestone conglomerates and breccias as related to the Chicxulub impact, and unconformities and hiatuses as caused by this impact. Sediment depositional patterns, impact spherule layers, minor iridium anomalies, short hiatuses and major unconformities through N. Atlantic, Caribbean, Gulf of Mexico and Central America are far too variable and complex for a simple one-size-fits-all interpretation.

\section{Conclusions}

Cretaceous-Tertiary sequences from Bass River (New Jersey), Blake Nose to Demerara Rise have been hailed as ultimate proof that the Chicxulub impact hit Yucatan at KTB time and caused the mass extinction. However, our detailed high-resolution biostratigraphic, faunal and stable isotope investigation reveals a fragmented sedimentary record for the KTB transition with a major unconformity that spans from the lower Danian across the KTB and well into the upper Maastrichtian, and impact spherules reworked and redeposited in early Danian Zone P1a (Figs 2-7). Similar early Danian records with multiple impact spherule layers and minor iridium anomalies have been published from the NW Atlantic, Haiti, Belize, Guatemala and southern Mexico, and Texas (Kramar et al. 2001; Stueben et al. 2002; Keller, 2008; Miller et al. 2010; Gertsch et al. 2011). Therefore, sequences in these regions have very incomplete sedimentary records with reworked impact spherule layers that provide no insight into the age of the Chicxulub impact. 
In contrast, KTB sequences in NE Mexico and Texas are more complete through to the upper Maastrichtian to early Danian and contain the stratigraphically oldest impact spherule deposits in the lower part of the latest Maastrichtian zone CF1, about 130-150 ka below the KTB. No significant species extinctions are associated with this impact spherule horizon (Keller et al. 2009, 2011). These results confirm our previous reports that the Chicxulub impact predates the KTB and cannot be the cause of the mass extinction, although it could have contributed through long term environmental changes. The real cause for the KTB mass extinction may have been India's Deccan Traps volcanism, where the main Deccan phase (80 \%) erupted during C29r over a short interval, coincident with rapid extinctions in planktic foraminifera, and ended at the KTB mass extinction (Keller et al. 2012).

The following biostratigraphic results and age determination of missing intervals are based on this study:

(1) Bass River core, NJ: The KTB unconformity spans from the early Danian subzone P1a(2) to P1a(1), P0, CF1 and CF2 for a total of about $620 \mathrm{ka}$ (Figs 2, 3, 11). The $6 \mathrm{~cm}$ thick impact spherule layer consists of eroded and redeposited debris.

(2) Blake Nose sites 1049A, 1049C, 1050C: The KTB unconformity spans from the early Danian subzone $\mathrm{P} 1 \mathrm{a}(1)$ to upper Maastrichtian zones CF1 and CF2 for a total of about $400 \mathrm{ka}$ (Figs 5, 6, 11). The $10 \mathrm{~cm}$ and $15 \mathrm{~cm}$ thick spherule layer was eroded and redeposited in the early Danian. The same unconformity is also present in Site 1050C where no spherules are present (Fig. 7).

(3) Caribbean sites $999 \mathrm{~B}$ and 1001B: The KTB unconformity at Sites $999 \mathrm{~B}$ and 1001B spans from Danian subzone P1a(1) to upper Maastrichtian zones $\mathrm{CF} 1, \mathrm{CF} 2, \mathrm{CF} 3, \mathrm{CF} 4$ for a total of about $3 \mathrm{Ma}$ (Figs 2, 8). Impact spherules at Site 1001B are eroded and redeposited in the early Danian (no spherules in site 999B).

(4) Demerara Site 1259B: A KTB hiatus spans most of subzone P1a(1) and zone P0 (total of 150-200 ka). Spherules appear to be reworked into early Danian sediments.

(5) Short hiatuses also occur in the early Danian at the $\mathrm{P} 1 \mathrm{a}(1)-\mathrm{P} 1 \mathrm{a}(2)$ and $\mathrm{Pla}(2)-\mathrm{P} 1 \mathrm{~b}$ boundaries in all sections examined and are likely linked to climate and sea level fluctuations. Similar hiatuses have been identified in many early Danian sequences worldwide.

(6) Abrupt negative and positive $\delta^{13} \mathrm{C}$ shifts observed in Sites 1049A, 1049C, 1050C, 1259B support the KTB and early Danian hiatuses and reflect low primary productivity and delayed post-KTB recovery of the ecosystem into zone $\mathrm{P} 1 \mathrm{~b}$.

(7) The widespread erosion and sedimentation pattern through the NW-SW Atlantic and Caribbean and the reworked impact spherules in lower Danian sediments rule this area out as indicator of the age of the Chicxulub impact.
Acknowledgements. We are grateful for the helpful comments and suggestions of the reviewers. Samples for this research were obtained from the Integrated Ocean Drilling Program (IODP), Bremen Core Repository (BCR), Germany, during two sampling visits in 2006 and 2011. We are grateful to Walter Hale, Repository Superintendent for his kind assistance during sampling. The material for this study is based upon work supported by the US National Science Foundation through the Continental Dynamics Program and Sedimentary Geology and Paleobiology Program under NSF Grants EAR-0207407 and EAR-0447171.

\section{References}

Abramovich, S. \& Keller, G. 2003. Planktonic foraminiferal response to the latest Maastrichtian abrupt warm event: a case study from South Atlantic DSDP Site 525A. Marine Micropaleontology 48, 225-49.

Abramovich, S., Keller, G., Berner, Z., Cymbalista, M. \& RAK, C. 2011. Maastrichtian planktic foraminiferal biostratigraphy and paleoenvironment of Brazos River, Falls County, Texas. In The End-Cretaceous Mass Extinction and the Chicxulub Impact in Texas (eds G. Keller \& T. Adatte), pp. 123-56. Society for Sedimentary Geology (SEPM), Special Publication no. 100.

Abramovich, S., Yovel-Corem, S., Almogi-Labin, A. \& Benjamini, C. 2010. Global climate change and planktic foraminiferal response in the Maastrichtian. Paleoceanography 25, PA2201.

Adatte, T., Keller, G. \& Baum, G. 2011. Age and origin of the Chicxulub impact and sandstone complex, Brazos River, Texas: evidence from lithostratigraphy, sedimentology and sequence stratigraphy. In The EndCretaceous Mass Extinction and the Chicxulub Impact in Texas (eds G. Keller \& T. Adatte), pp. 43-80. Society for Sedimentary Geology (SEPM), Special Publication no. 100.

Adatte, T., Keller, G. \& Stinnesbeck, W. 2002. Late Cretaceous to early Paleocene climate and sea-level fluctuations. Palaeogeography, Palaeoclimatology, Palaeoecology 178, 165-98.

Adatte, T., Stinnesbeck, W. \& Keller, G. 1996. Lithostratigraphic and mineralogical correlations of near-K-T boundary clastic sediments in northeastern Mexico: implications for origin and nature of deposition. In The Cretaceous-Tertiary Event and Other Catastrophes in Earth History (eds G. Ryder, D. E. Fastovsky \& S. Gartner), pp. 211-26. Geological Society of America, Special Paper no. 307.

Alegret, L., Arenillas, I., ArZ, J. A., Diaz, C., GrajalesNishimura, J. M., MElEndeZ, A., Molina, E., RoJAs, R. \& SoRIA, A. R. 2005. Cretaceous-Paleogene boundary deposits at Loma Capiro, central Cuba: evidence for the Chicxulub impact. Geology 33(9), 721-24.

Alegret, L., Arenillas, I., ArZ, J. A., Liesa, C., Melendez, A., Molina, E., Soria, A. R. \& ThOmas, E. 2002. The Cretaceous/Tertiary boundary: sedimentology and micropaleontology at the El Mulato section, NE Mexico. Terra Nova 14(5), 330-6.

ARENILlas, I., ARZ, J. A., GRAJALES-NISHIMURA, J. M., Murillo-Muneton, G., Alvarez, W., CAMARgo-Zanguera, A., Molina, E. \& Rosales-DomingueZ, C. 2006. Chicxulub impact event is Cretaceous/Paleogene boundary in age: new micropaleontological evidence. Earth and Planetary Science Letters 249, 241-57. 
Alegret, L., Molina, E. \& Thomas, E. 2001. Benthic foraminifera at the Cretaceous/Tertiary boundary around the Gulf of Mexico. Geology 29(10), 891-4.

Alegret, L. \& Thomas, E. 2004. Benthic foraminifera and environmental turnover at the Cretaceous/Paleogene boundary at Blake Nose (ODP Hole 1049C, Northwestern Atlantic. Palaeogeography, Palaeoclimatology, Palaeoecology 208, 59-83.

ARZ, J. A., AlEgret, L. \& ARENILlas, I. 2004. Foraminiferal biostratigraphy and paleoenvironmental reconstruction at the Yaxcopoil-1 drill hole (Chicxulub crater, Yucatan Peninsula). Meteoritics and Planetary Science 39, 1099-112.

Arz, J. A., Arenillas, I., Soria, A. R., Alegret, L., GrajAles-Nishimura, J. M., LiEsA, C. L., MELÉndeZ, A., Molina, E. \& Rosales, M. C. 2001. Micropaleontology and sedimentology across the Cretaceous/Tertiary boundary at La Ceiba (Mexico): impact-generated sediment gravity flows. Journal of South American Earth Sciences 14, 505-19.

Berggren, W. A., Kent, D. V., Swisher, C. C. \& Aubry, M.-P. 1995. A revised Cenozoic geochronology and chronostratigraphy. In Geochronology, Time Scales and Global Stratigraphic Correlation (eds W. A. Berggren, D. V. Kent, M. P. Aubry, \& J. Hardenbol), pp. 129212. Society for Sedimentary Geology (SEPM), Special Publication no. 54.

Bourgeois, J., Hansen, T. A., Wiberg, P. \& Kauffman, E. G. 1988. A tsunami deposit at the Cretaceous-Tertiary boundary in Texas. Science 141, 567-70.

Bralower, T. J., Paull, C. K. \& Leckie, R. M. 1998. The Cretaceous/Tertiary boundary cocktail: Chicxulub impact triggers margin collapse and extensive sediment gravity flows. Geology 26, 331-4.

CANDE, S. \& KENT, D. V. 1995. Revised calibration of the geomagnetic polarity timescale for the Late Cretaceous and Cenozoic. Journal of Geophysical Research 100, 6093-5.

Colodner, D. C., Boyle, E. A., Edmond, J. M. \& THOMSON, J. 1992. Post-depositional mobility of platinum, iridium, and rhenium in marine sediments. Nature 358, 402-4.

CowIE, J. W., ZiEgler, W. \& REMANE, J. 1989. Stratigraphic Commission accelerates progress, 1984 to 1989. Episodes 12, 79-83.

EkdALE, A. A. \& Stinnesbeck, W. 1998. Ichnology of Cretaceous-Tertiary $(\mathrm{K} / \mathrm{T})$ boundary beds in northeastern Mexico. Palaios 13, 593-602.

GALE, A. S. 2006. The Cretaceous-Palaeogene boundary on the Brazos River, Falls County, Texas: is there evidence for impact-induced tsunami sedimentation? Proceedings of the Geologists' Association 117, 17385.

Gertsch, B., Keller, G., AdAtte, T. \& Berner, Z. 2011. Platinum group element (PGE) geochemistry of Brazos Sections, Texas. In End-Cretaceous Mass Extinction and the Chicxulub Impact in Texas (eds G. Keller \& T. Adatte), pp. 228-49. Society for Sedimentary Geology (SEPM), Special Publication no. 100.

Gradstein, F., OGG, J. \& SMith, A. 2004. A Geologic Time Scale. Cambridge: Cambridge University Press, 598 pp.

Graup, G. \& SpetTel, B. 1989. Mineralogy and phasechemistry of an Ir-enriched pre-K/T layer from the Lattengebirge, Bavarian Alps, and significance for the KTB problem. Earth and Planetary Science Letters 95 , 271-90.

Huber, B. T., Macleod, K. G. \& Norris, R. D. 2002. Abrupt extinction and subsequent reworking of Cretaceous planktonic foraminifera across the $\mathrm{K} / \mathrm{T}$ boundary: evidence from the subtropical North Atlantic, In Catastrophic Events and Mass Extinctions: Impacts and Beyond (eds C. Koeberl \& K. MacLeod), pp. 227 89. Geological Society of America, Special Paper no. 356.

Huber, B. T., Macleod, K. G. \& TuR, N. A. 2008. Chronostratigraphic framework for upper CampanianMaastrichtian sediments on the Blake Nose (Subtropical North Atlantic). Journal of Foraminiferal Research 38(2), 162-82.

KELLER, G. 2008. Impact stratigraphy: old principle - new reality. In The Sedimentary Record of Meteorite Impacts (eds K. R. Evans, J. W. Horton \& D. T. King), pp. 14778. Geological Society of America, Special Paper no. 437.

KELLER, G. 2011a. The Cretaceous-Tertiary mass extinction: theories and controversies, In The End-Cretaceous Mass Extinction and the Chicxulub Impact in Texas (eds G. Keller \& T. Adatte), pp. 7-22. Society for Sedimentary Geology (SEPM), Special Publication no. 100.

KelleR, G. 2011b. Defining the Cretaceous-Tertiary Boundary: a practical guide and return to first principles. In The End-Cretaceous Mass Extinction and the Chicxulub Impact in Texas (eds G. Keller \& T. Adatte), pp. 23-42. Society for Sedimentary Geology (SEPM), Special Publication no. 100.

Keller, G., Abramovich, S., Adatte, T. \& Berner, Z. 2011. Biostratigraphy, age of the Chicxulub impact and depositional environment of the Brazos River KT sequences. In The End-Cretaceous Mass Extinction and the Chicxulub Impact in Texas (eds G. Keller \& T. Adatte), pp. 81-122. Society for Sedimentary Geology (SEPM), Special Publication no. 100.

Keller, G. \& ADATTE, T. 2011. The End-Cretaceous Mass Extinction and the Chicxulub Impact in Texas. Society for Sedimentary Geology (SEPM), Special Publication no. 100, 315pp.

Keller, G., AdATte, T., Baum, G. \& Berner, Z. 2008. Reply to 'Chicxulub impact Predates K-T boundary: new evidence from Brazos, Texas' comment by Schulte et al. Earth and Planetary Science Letters 269, 621-9.

Keller, G., AdATte, T., Berner, Z., HARTing, M., BAuM, G., Prauss, M., Tantawy, A. A. \& Stueben, D. 2007. Chicxulub impact predates K-T Boundary: new evidence from Texas. Earth and Planetary Science Letters 255, 339-56.

Keller, G., Adatte, T., Berner, Z., Pardo, A. \& LOPEZ-OlIVA, L. 2009. New evidence concerning the age and biotic effects of the Chicxulub impact in Mexico. Journal of the Geological Society, London 166, 393 411.

Keller, G., Adatte, T., Bhowmick, P. K., Upadhyay, H., DAVE, A., REDDY, A. N., JAIPRAKASH, B. C. 2012. Nature and timing of extinctions in Cretaceous-Tertiary planktic foraminifera preserved in Deccan intertrappean sediments of the Krishna-Godavari Basin, India. Earth and Planetary Science Letters 341-344, 211-21.

Keller, G., Adatte, T., Stinnesbeck, W., Luciani, V., KAROUI, N. \& ZAGHBIB-TURKI, D. 2002. Paleoecology of the Cretaceous-Tertiary mass extinction in planktic foraminifera. Palaeogeography, Palaeoclimatology, $\mathrm{Pa}$ laeoecology 178, 257-98.

Keller, G., AdATte, T. \& Stinnesbeck, W. $2004 a$. More evidence that Chicxulub predates KT boundary. Meteoritics and Planetary Science 39(6/7), 1127-44.

Keller, G., Adatte, T., Stinnesbeck, W., RebolledoVIEYRA, M., URRUtia FucUgauchi, J., Kramar, U. 
\& Stueben, D. 2004b. Chicxulub crater predates K-T boundary mass extinction. Proceedings of the National Academy of Sciences (PNAS) 101(11), 3721-992.

Keller, G., AdATte, T., Stinnesbeck, W., Stueben, D. \& BERNER, Z. 2001. Age, chemo- and biostratigraphy of Haiti spherule-rich deposits: a multi-event K-T scenario. Canadian Journal of Earth Sciences 38, 197-227.

Keller, G., Li, L. \& MACLeOD, N. 1995. The Cretaceous/Tertiary boundary stratotype section at El Kef, Tunisia: how catastrophic was the mass extinction? $\mathrm{Pa}$ laeogeography, Palaeoclimatology, Palaeoecology 119, 221-54.

Keller, G. \& Lindinger, M. 1989. Stable isotope, TOC and $\mathrm{CaCO}_{3}$ record across the Cretaceous/Tertiary boundary at El Kef, Tunisia. Palaeogeography, Palaeoclimatology, Palaeoecology 73(3/4), 243-65.

Keller, G., LOPeZ-Oliva, J. G., Stinnesbeck, W. \& ADATTE, T. 1997. Age, stratigraphy and deposition of near-K/T siliciclastic deposits in Mexico: relation to bolide impact? Geological Society of America Bulletin 109, 410-28.

Keller, G., Lyons, J. B., Macleod, N. \& Officer, C. B. 1993. Is there evidence for Cretaceous-Tertiary boundary impact deposits in the Caribbean and Gulf of Mexico? Geology 21, 776-80.

Keller, G., Stinnesbeck, W., Adatte, T., Holland, B., Stueben, D., Harting, M., De Leon, C. \& DE LA CRUZ, J. 2003a. Spherule deposits in CretaceousTertiary boundary sediments in Belize and Guatemala. Journal of the Geological Society, London 160, 1-13.

Keller, G., Stinnesbeck, W., AdAtte, T. \& Stueben, D. 2003b. Multiple impacts across the Cretaceous-Tertiary boundary. Earth-Science Reviews 62, 327-63.

Klaus, A., Norris, R. D., KroON, D. \& Smit, J. 2000. Impact-induced mass wasting at the K-T boundary: Blake Nose, western North Atlantic. Geology 28, 31922.

Kramar, U., Stueben, D., Berner, Z., Stinnesbeck, W., Philipp, H. \& Keller, G. 2001. Are Ir anomalies sufficient and unique indicators for cosmic events? Planetary and Space Science 49, 831-7.

Lee, C.-T., A., Wasserburg, G. J. \& Kyte, F. T. 2003. Platinum-group elements (PGE) and rhenium in marine sediments across the Cretaceous-Tertiary boundary: constraints on Re-PGE transport in the marine environment. Geochimica et Cosmochimica Acta 67(4), 655-70.

LI, L. \& KelleR, G. 1998a. Abrupt deep-sea warming at the end of the Cretaceous. Geology 26(11), 995-8.

LI, L. \& KelleR, G. 1998b. Diversification and extinction in Campanian-Maastrichtian planktic foraminifera of northwestern Tunisia. Eclogae Geologica Helvetica 91, $75-102$.

LI, L. \& KelleR, G. 1998c. Maastrichtian climate, productivity and faunal turnovers in planktic foraminifera in South Atlantic DSDP Sites 525A and 21. Marine Micropaleontology 33, 55-86.

LOPEZ-Oliva, J. G. \& KeLLER, G. 1996. Age and stratigraphy of near-K/T boundary clastic deposits in NE Mexico. Geological Society of America, Special Paper 307, 22742.

MACLEOD, N. \& Keller, G. 1991a. Hiatus distribution and mass extinctions at the Cretaceous-Tertiary boundary. Geology 19, 497-501.

MACLeOD, N. \& KelleR, G. 1991b. How complete are Cretaceous/Tertiary boundary sections? A chronostratigraphic estimate based on graphic correlation. Geological Society of America Bulletin 103, 143957.
MacLeod, K. G., Whitney, D. L., Huber, B. T. \& KoeberL, C. 2007. Impact and extinction in remarkably complete Cretaceous-Tertiary boundary sections from Demerara Rise, tropical western North Atlantic. Geological Society of America Bulletin 119, 101-15.

Martinez-Ruiz, F., Ortega-Huertas, M., PalomoDELGADO, I. \& SMIT, J. 2001. K-T boundary spherules from Blake Nose (ODP Leg 171B) as a record of the Chicxulub ejecta deposits. In Western North Atlantic Paleogene and Cretaceous Paleoceanography (eds D. Kroon, R. D. Norris \& A. Klaus), pp. 149-61 Geological Society of London, Special Publication no. 183.

MAURRASSE, F. J.-M. R. \& SEN, G. 1991. Impacts, tsunamis, and the Haitian Cretaceous-Tertiary boundary layer. Science 252, 1690-3.

Miller, K. G., Sherrell, R. M., Browning, J. V., Field, M. P., GALlaGHER, W., OlsSON, R. K., SUGARMAN, P. J., TUORTO, S. \& WAHYUDI, H. 2010. Relationship between mass extinction and iridium across the CretaceousPaleogene boundary in New Jersey. Geology 28, 867-70.

Miller, K. G., Sugarman, P. J., Browning, J. V., OlsSON, R.K., PeKar, S. F., Reilly, T. H., Cramer, B. S., Aubry, M.-P., LAWRENCE, R. P., CURRAN, J., STEWART, M., Metzger, J. M., Uptegrove, J., BuKry, D., Burckle, L. H., Wright, J. D., Feigenson, M. D., BRENNER, G. J. \& DALTON, R. F. 1998. Bass River Site. In Proceedings of the Ocean Drilling Program, Initial Reports vol. 174AX, pp. 5-43. College Station, Texas. Doi: 10.2973/odp.proc.ir.174AX.101.1998

Molina, E., Alegret, L., Arenillas, I., ArZ, J. A., Gallala, N., Hardenbol, J., VON SAlis, K., Steurbaut, E., VANDENBERGHe, N. \& ZaghBIBTURKI, D. 2006. The global boundary stratotype section and point for the base of the Danian Stage (Paleocene, Paleogene, 'Tertiary', Cenozoic) at El Kef, Tunisia original definition and revision. Episodes 29, 263-73.

Norris, R. D., FirTH, J., BluszTAJN, J. \& RAVIZZA, G. 2000. Mass failure of the North Atlantic margin triggered by the Cretaceous-Paleogene bolide impact. Geology $\mathbf{2 8}$, 1119-22.

Norris, R. D., Huber, B. T. \& Self-Trail, J. 1999. Synchroneity of the KT oceanic mass extinction and meteorite impact: Blake Nose, western North Atlantic. Geology 27, 419-22.

Norris, R. D., KroOn, D., Klaus, A. et al. 1998. Site 1049. In Proceedings of the Ocean Drilling Program, Initial Reports, vol. $171 B$ (eds L. A. Baez \& E. Kapitan-White), pp. 47-86. College Station, Texas.

Olsson, R. K., Miller, K. G., Browning, J. V., HABIB, D. \& SugarmanN, P. J. 1997. Ejecta layer at the Cretaceous-Tertiary boundary, Bass River, New Jersey (Ocean Drilling Program Leg 174AX). Geology 25, 759-62.

Prauss, M. L. 2009. The K/Pg boundary at Brazos River, Texas - an approach by marine palynology. Palaeogeography, Palaeoclimatology, Palaeoecology 283, 195215.

Remane, J., Keller, G., Hardenbol, J. \& Ben Haj Ali, M. 1999. Report on the International Workshop on Cretaceous-Paleogene Transitions. Episodes 22(1), 47 8.

Revesz, K. M., Landwehr, J. M. \& KeYBl, J. 2001. Measurement of $\delta^{13} \mathrm{C}$ and $\delta^{18} \mathrm{O}$ Isotope Ratios of $\mathrm{CaCO}_{3}$ Using a Thermoquest Finnigan GasBench II Delta Plus XL Continuous Flow Isotope Ratio Mass Spectrometer With Application to Devils Hole Core DH-11 Calcite. US Geological Survey Open-File-Report 01-257, $17 \mathrm{pp}$. 
Schrag, D. P., DePaolo, D. J. \& Richter, F. M. 1995. Reconstructing past sea surface temperatures from oxygen isotope measurements of bulk carbonate. Geochimica et Cosmochimica Acta 59, 2265-78.

Schulte, P., Alegret, L., Arenillas, I. et al. 2010. The Chicxulub asteroid impact and mass extinction at the Cretaceous-Paleogene boundary. Science 327, 1214-18.

Schulte, P., Deutsch, A., SAlge, T., Berndt, J., Kontny, A., Macleod, K., Neuser, R. D. \& KRUMM, S. 2009. A dual-layer Chicxulub ejecta sequence with shocked carbonates from the CretaceousPaleogene (K-Pg) boundary, Demerara Rise, western Atlantic. Geochimica et Cosmochimica Acta 73, 1180 204.

Schulte, P., Speijer, R. P., Brinkhuis, H., Kontny, A., Caleys, P., Galeotti, S. \& Smit, J. 2008. Comment on the paper; 'Chicxulub impact predates $\mathrm{K}-\mathrm{T}$ boundary: new evidence from Brazos, Texas' by Keller et al. (2007). Earth and Planetary Science Letters 269, 61319.

Schulte, P., Speijer, R. P., Mai, H. \& Kontny, A. 2006. The Cretaceous-Paleogene (K-P) boundary at Brazos, Texas: sequence stratigraphy, depositional events and the Chicxulub impact. Sedimentary Geology 184, 77109.

Schulte, P., Stinnesbeck, W., Stueben, D., Kramar, U., Berner, Z., Keller, G. \& Adatte, T. 2003. Ferich and K-rich mafic spherules from slumped and channelized Chicxulub ejecta deposits in the northern La Sierrita area, NE Mexico. International Journal of Earth Sciences 92, 114-42.

ShIPBOARD SCIENTIFIC PARTY 2004. Site 1259. In Proceedings of the Ocean Drilling Program, Initial Reports, vol. 207 (eds J. Erbacher, D. C. Mosher, M. J. Malone et al.), pp. 1-110. College Station, Texas.

SiguRdSSON, H., LeCKIE, R. M., ACTON, G. D. et al. 1997. Caribbean volcanism, Cretaceous/Tertiary impact, and ocean-climate history: synthesis of leg 165. In Proceedings of the Ocean Drilling Program, Initial Reports vol. 165 (eds C. M. Miller \& E. M. Maddox), pp. 377-400. College Station, Texas.

SMIT, J. 1999. The global stratigraphy of the CretaceousTertiary boundary impact ejecta. Annual Review of Earth and Planetary Sciences 27, 75-113.

Smit, J., Montanari, A., Swinburne, N. H. M., Alvarez, W., Hildebrand, A. R., Margolis, S. V., Claeys, P., LORIE, W. \& ASARO, F. 1992. Tektite-bearing, deepwater clastic unit at the Cretaceous-Tertiary boundary in northeastern Mexico. Geology 20, 99-103.

Smit, J., Roep, T. B., Alvarez, W., Montanari, A., Claeys, P., Grajales-Nishimura, J. M. \& Bermudez, J. 1996. Coarse-grained clastic sandstone complex at the $\mathrm{K} / \mathrm{T}$ boundary around the Gulf of Mexico: deposition by tsunami waves induced by the Chicxulub impact.
Geological Society of America, Special Paper 307, 15182.

SMit, J., VAN DER GAASt, S. \& LuSTENHOUWER, W. 2004. Is the transition to post-impact rock complete? Some remarks based on XRF sanning, electron-microprobe and thin section analyses of the Yaxcopoil-1 core in the Chicxulub crater. Meteoritics and Planetary Science 39(6), 1-14.

Sohl, N. F., Martinez, R. E., SAlmerón-Ureña, P. \& SOTO-JARAMILLO, F. 1991. Upper Cretaceous. In Geology of North America: The Gulf of Mexico Basin (ed. A. Salvador), pp. 205-44. Boulder: Geological Society of America.

StinNesbeCK, W., BARBARIN, J. M., Keller, G., LOPEZ-Oliva, J. G., PIVNIK, D. A., LYONS, J. B., OfFicer, C. B., AdATte, T., Graup, G., Rocchia, R. \& RoBIN, E. 1993. Deposition of near K/T Boundary clastic sediments in NE Mexico: impact or turbidite deposits? Geology 21, 797-800.

Stinnesbeck, W., Keller, G., Schulte, P., Stueben, D., Berner, Z., Kramar, U. \& LOPEZ-Oliva, J. G. 2002. The Cretaceous-Tertiary $(\mathrm{K} / \mathrm{T})$ boundary transition at Coxquihui, State of Veracruz, Mexico: evidence for an early Danian impact event? Journal of South American Research 15, 497-509.

Stueben, D., Kramar, U., Berner, Z., Eckhardt, J. D., Stinnesbeck, W., Keller, G., AdATte, T. \& Heide, K. 2002. Two anomalies of platinum group elements above the Cretaceous-Tertiary boundary at Beloc, Haiti: geochemical context and consequences for the impact scenario. Geological Society of America, Special Paper 356, 163-88.

Stueben, D., Kramar, U., Harting, M., Stinnesbeck, W. \& Keller, G. 2005. High-resolution geochemical record of Cretaceous-Tertiary boundary sections in Mexico: new constraints in the $\mathrm{K} / \mathrm{T}$ and Chicxulub events. Geochimica et Cosmochimica Acta 69, 255979.

TANTAWY, A. A. 2003. Calcareous nannofossil biostratigraphy and paleoecology of the Cretaceous-Tertiary transition in the western desert of Egypt. Marine Micropaleontology 47, 323-56.

THIBAULT, N. \& GARDIN, S. 2006. Maastrichtian calcareous nannofossil biostratigraphy and paleoecology in the Equatorial Atlantic (Demerara Rise, ODP Leg 207 Hole 1258A). Revue de Micropaléontology 49, 199-214.

WatKins, D. K. \& Self-Trail, J. M. 2005. Calcareous nannofossil evidence for the existence of the Gulf Stream during the late Maastrichtian. Paleoceanography 20, PA3006.

Zachos, J. C., Arthur, M. A. \& DeAn, W. E. 1989. Geochemical evidence for suppression of pelagic marine productivity at the Cretaceous/Tertiary boundary. Nature 337, 61-4. 